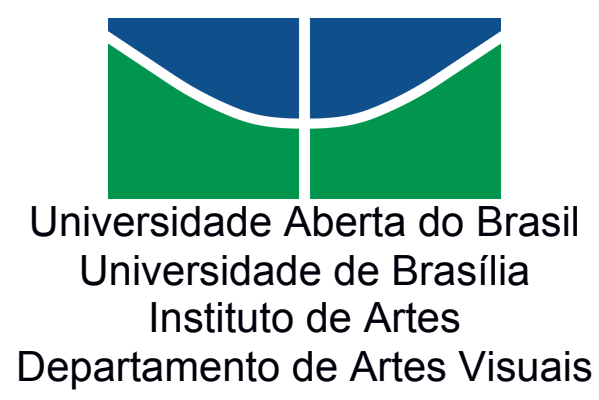

Intervenção Urbana como Manifestação Artística no Município de Sena Madureira/AC

Gerliana Cavalcante Neres

Sena Madureira/AC

2017 


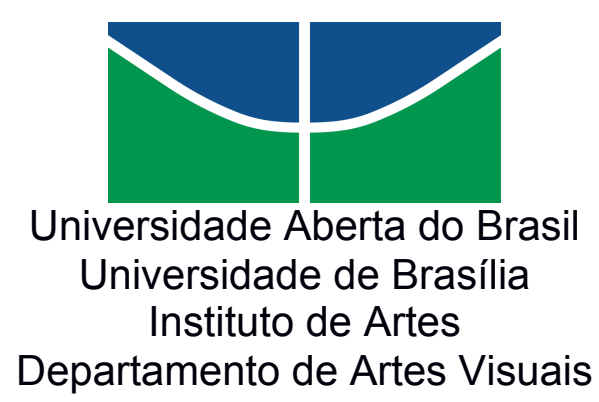

Gerliana Cavalcante Neres

\section{Intervenção Urbana como Manifestação Artística no Município de Sena Madureira/AC}

Trabalho de Conclusão de Curso em Artes Visuais, apresentado ao Departamento de Artes Visuais da Universidade de Brasília, como prérequisito para obtenção do título de graduada em Licenciatura em Artes Visuais.

Orientador: Prof. Ms. Clerismar Aparecido Longo 
Intervenção Urbana como Manifestação Artística no Município de Sena Madureira/AC

Trabalho de Conclusão de Curso em Artes Visuais, apresentado ao Departamento de Artes Visuais da Universidade de Brasília, como pré-requisito para obtenção do título de graduada em Licenciatura em Artes Visuais.

Banca Examinadora

Prof. Ms. Clerismar Aparecido Longo (UAB/UnB)

Presidente

Prof. Dr. Luiz Carlos Pinheiro Ferreira (IdA/UnB)

Membro examinador

Profa. Dra. Lisa Minari Hargreaves (IdA/UnB)

Membra examinadora 
Dedico este trabalho a Deus e, em especial, a uma pessoa que teve papel fundamental no decorrer deste trabalho, que me deu total apoio durante todo o processo, disponibilizando sua casa e seu tempo para poder me ajudar nessa etapa tão importante em minha vida: Núcia Sabóia. 


\section{AGRADECIMENTOS}

Agradeço sobretudo a Deus, por ter me dado forças e muita sabedoria para poder enfrentar esses quatros anos de muitas lutas e dificuldades encontradas no decorrer de minha trajetória, durante o curso de Licenciatura em Artes Visuais, pois, sem Ele, eu não teria chegado até aqui.

Em especial, agradeço a Núcia Sabóia que, mesmo não sendo mais nossa tutora à distância, sempre mostrou disponibilidade em me ajudar. Obrigada por tudo, por ser essa pessoa de um enorme coração! Você foi parte fundamental na realização deste trabalho.

Ao meu amor, Awlieiny Viana Gadelha, por sempre estar ao meu lado fazendo parte de toda trajetória de minha vida. Durante o decorrer do curso, sempre me ajudou nos momentos que precisei, me incentivando e acreditando no meu sucesso. Obrigado por estar ao meu lado meu amor, tua presença foi muito importante para essa conquista em minha vida!

A toda minha família, por sempre acreditar no meu potencial, em especial, à minha mãe, Raimunda Cavalcante, e ao meu pai, Valderí Ferreira. Às minhas amigas e colegas de curso, que estiveram presentes, desde o início do curso, sempre me apoiando e me ajudando, Aldenice Gonçalves e Francielly Brito; e à coordenadora do polo UAB, em Sena Madureira, Francisca Almeida do Carmo.

Ao professor orientador Clerismar Aparecido Longo que me auxiliou durante o processo do trabalho, que mesmo à distância sempre mostrou disponibilidade durante todo o processo deste Trabalho de Conclusão de Curso.

Durante o decorrer do curso, foram muitos tutores que fizeram parte na contribuição de meu aprendizado. Obrigado a todos que, de alguma forma, participaram direta ou indiretamente para a realização deste sonho. 


\section{RESUMO}

O presente Trabalho de Conclusão de Curso teve como objetivo abordar a Intervenção Urbana como Manifestação Artística no Município de Sena Madureira/AC, mostrando a importância que essa linguagem tem no universo artístico e as primeiras manifestações realizadas no município. Nesse sentido, tentei destacar as contribuições no uso da referida linguagem para a sociedade local, enquanto algo que pode proporcionar sensibilidade, curiosidade, imaginação, conhecimento e criticidade em relação a determinadas questões sociais. Para tanto, fiz uma intervenção urbana sobre meio ambiente e uma instalação sobre abuso sexual infantil, de modo que o público externo pudesse interagir com as produções e refletirem sobre as questões abordadas.

Palavras- Chave: Intervenção, Manifestação, Linguagem Artística. 


\begin{abstract}
The present work of Conclusion Course aimed to address the Urban Intervention as Artistic Manifestation in the city of Sena Madureira / AC, showing the importance that this language has in the artistic universe and the first demonstrations in this city. In this sense, I have tried to emphasize the contributions of the use of this language to the local society, something that can provide sensitivity, curiosity, imagination, knowledge and criticism in relation to certain social questions. To do so, I made an urban intervention on the environment and a facility on child sexual abuse, so that the external public could interact with the productions and reflect on the issues addressed.
\end{abstract}

Keywords: Intervention, Manifestation, Artistic Language. 


\section{LISTA DE FIGURAS}

Figura 1: Intervenção urbana que causou grande impacto, de Artur Barrio (1969) ............14

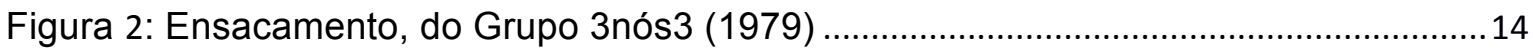

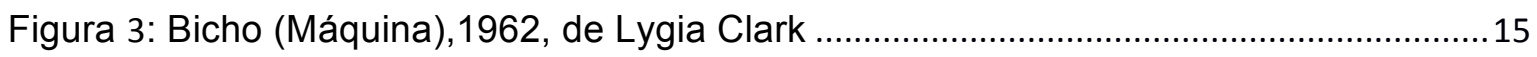

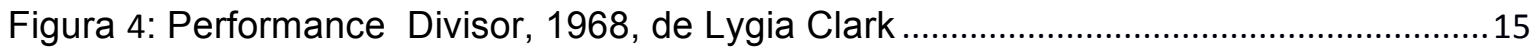

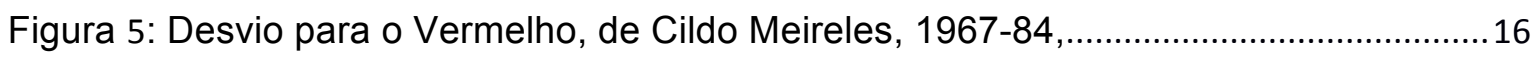

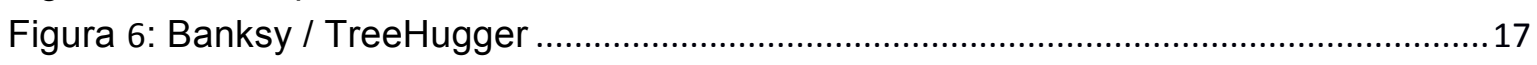

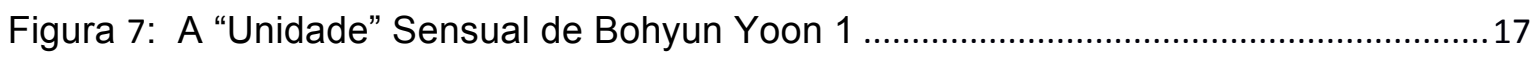

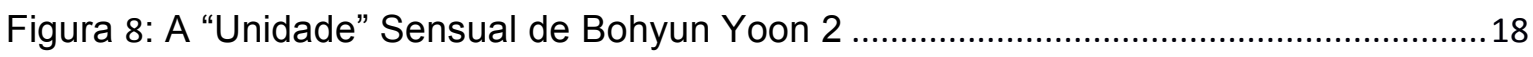

Figura 9: Pets gigantes nas margens do rio Tietê.............................................................. 19

Figura 10: Intervenção 'Caiaques' no rio Pinheiros..............................................................19

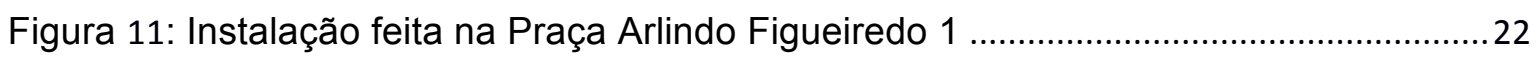

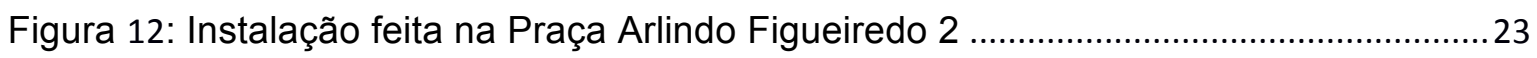

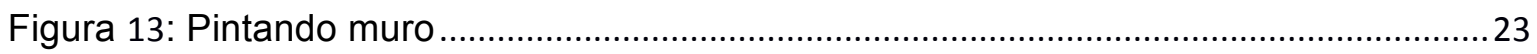

Figura 14: Intervenção na parede da Igreja Nossa Senhora da Conceição............................24

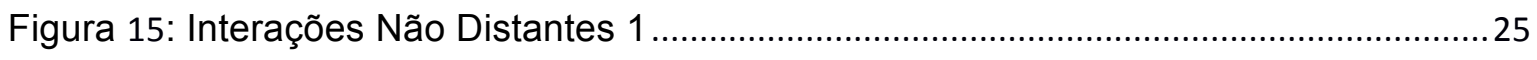

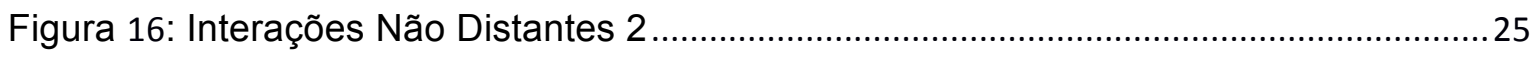

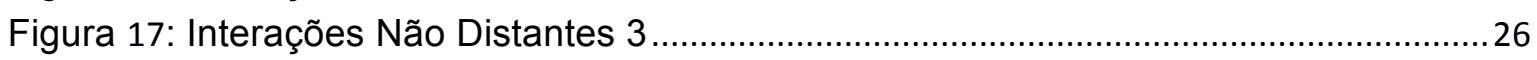

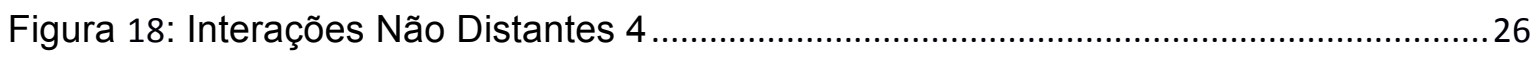

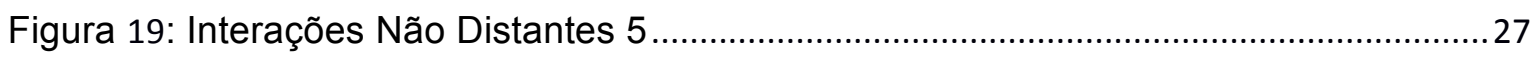

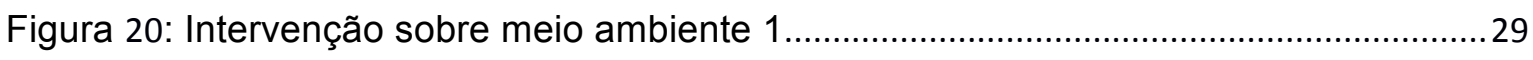

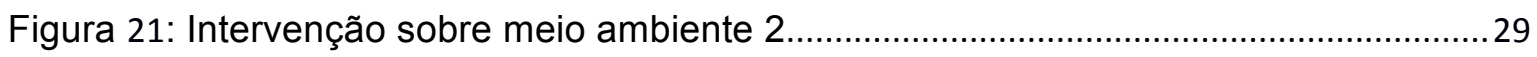

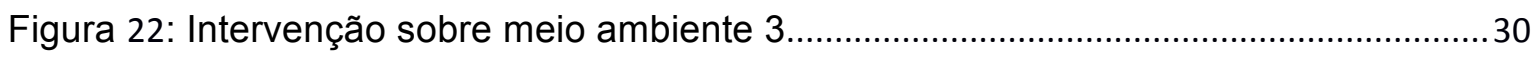

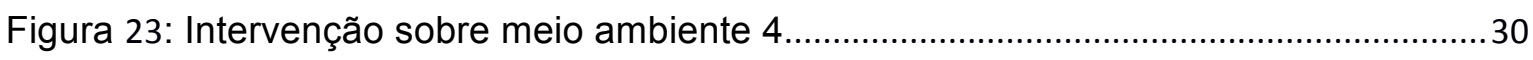

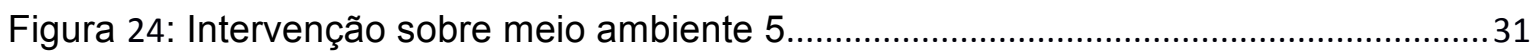

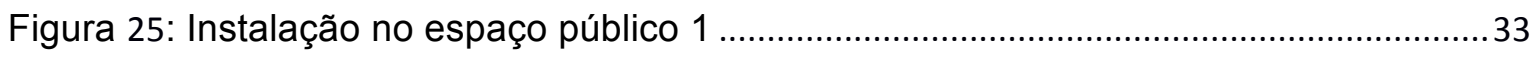

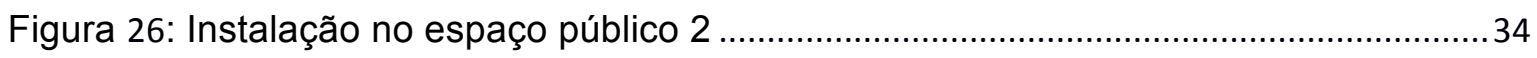

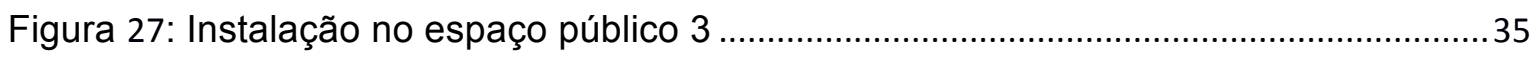

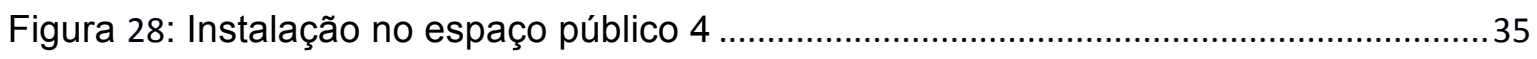

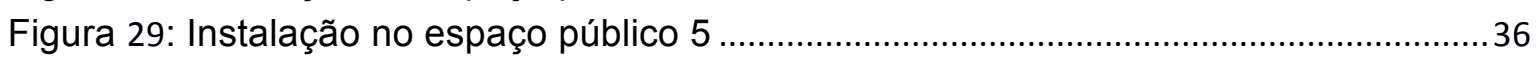


SUMÁRIO

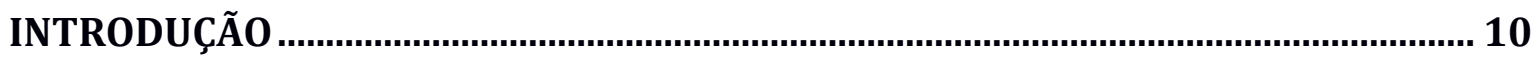

CAPÍTULO I - INTERVENÇÃO URBANA: UMA FORMA DE INTERAÇÃO DO SER

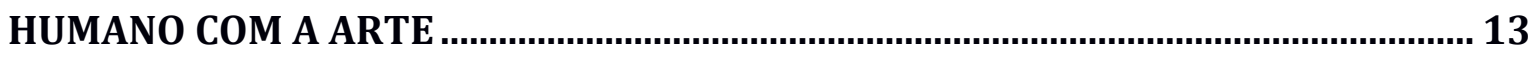

CAPÍTULO II - PROJETOS DE INTERVENÇõES E AÇõES EM SENA MADUREIRA .. 20 CAPÍTULO III - COLOCANDO NA PRÁTICA O CONHECIMENTO ADQUIRIDO EM

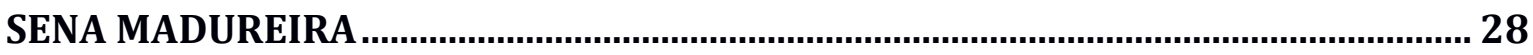

3.1 Intervenção Urbana ..................................................................................................... 28

3.2 Instalação no Espaço Público ............................................................................................... 31

3.2.1 Como o público reagiu diante da obra ......................................................................... 36

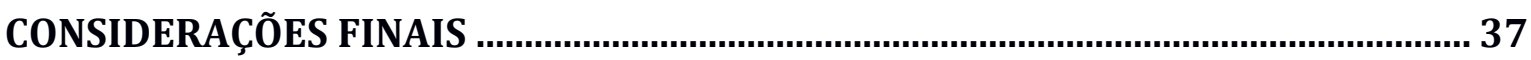

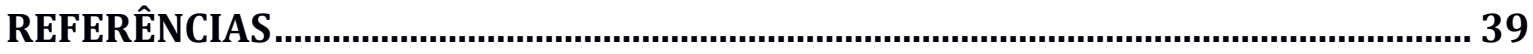




\section{INTRODUÇÃO}

Este trabalho, de cunho exploratório, teve como objetivo apresentar a Intervenção Urbana como manifestação artística no Município de Sena Madureira/AC, enfatizando a importância que a mesma teve e suas primeiras manifestações realizadas no município.

O interesse em realizar uma pesquisa voltada para a linguagem artística Intervenção Urbana surgiu da necessidade de dar visibilidade para mesma na cidade. Sabemos que a Intervenção Urbana é uma linguagem que pode transformar um espaço público ou parte dele em arte ou por meio da arte. Dada a sensação de aceleração do tempo em nossa contemporaneidade, os espaços citadinos, muitas vezes, passam despercebidos no nosso dia a dia. Com o fito de aguçar a sensibilidade das pessoas, buscando uma nova forma de olhar a realidade, alguns artistas mudam o visual de muros e paredes de prédios, usando a prática da Intervenção Urbana para atrair o olhar das pessoas para lugares que, majoritariamente, não são notados pelos sujeitos.

Realizar o trabalho que esteja ligado a essa linguagem será importante tanto para o pesquisador quanto para a sociedade local. Além de ser possível abordar algo que desperte a atenção das pessoas, a linguagem da intervenção é um trabalho satisfatório enquanto pesquisa, dado o envolvimento que ela exige do pesquisador/interventor. Por meio da intervenção urbana, poderei abordar, utilizando-se da arte, assuntos importantes, tais como abuso infantil, degradação do meio ambiente, dentre outros assuntos/problemas, chamando a atenção da sociedade para a gravidade desses problemas na atualidade. Nesse sentido, a referida arte tem um viés pedagógico de conscientização e reeducação social.

A intervenção é uma linguagem artística que, há algum tempo, tem me despertado o interesse em trazê-la para perto da minha realidade aqui em Sena Madureira, pois, em nossa região, infelizmente, não se vê muitas manifestações artísticas. Nesse sentido, o desenvolvimento da pesquisa e a 
prática da intervenção em alguns pontos da cidade contribuirão para tornar mais estreita a relação da comunidade local com a arte.

A Intervenção Urbana, enquanto manifestação artística das Artes Visuais, é uma linguagem que possibilita tratar diferentes temas da vida cotidiana, não só no sentido de dar maior visibilidade a esses temas, mas também como forma de sensibilizar e reeducar o ser humano no que se refere às demandas sociais ligadas aos direitos humanos, racismo, desigualdade de gênero, abuso sexual, sexualidade, meio ambiente, dentre outros. Nesse sentido, a intervenção abre o leque de possibilidades de atuação artística para fora de locais fechados como, por exemplo, os museus, mostrando ao público uma forma diferente de interação com as artes e, ao mesmo tempo, facilita o acesso do público a essa linguagem.

Tendo em vista o exposto, o presente trabalho teve como objetivo geral:

> Mostrar a importância da Intervenção Urbana como manifestação artística na cidade de Sena Madureira/AC.

E como objetivos específicos:

> Utilizar a Intervenção Urbana como meio para alertar determinadas demandas sociais ligadas a questões sociais;

> Perceber como as pessoas reagem diante de um trabalho de Intervenção que aborda questões sociais que precisam ser discutidas com um pouco de leveza;

> Mostrar a importância de realizar manifestações artísticas no contexto local para o aprendizado artístico;

$>$ Dar maior visibilidade à intervenção urbana como uma forma de conscientização e reeducação social.

A Metodologia utilizada para o desenvolvimento deste trabalho se deu por meio de pesquisa bibliográfica sobre arte contemporânea, intervenção urbana, e trabalho monográfico que abordam a intervenção urbana como o da Núcia Sabóia e por meio de instalações em espaços públicos, feitas pela autora desta monografia, com o fito de colocar o aprendizado em prática. 
As fontes bibliográficas sobre intervenção urbana e instalações foi de extrema importância para este trabalho, pois pude perceber como os artistas, na prática, experienciaram essa linguagem na transformação de ambientes públicos, ressignificando-os.

As pesquisas que resultaram nesta monografia estão dispostas em três capítulos, a saber:

No capítulo I, Intervenção urbana: uma forma de interação do ser humano com a arte, abordo o surgimento da Intervenção no Brasil, uma linguagem artística contemporânea, com uso de estratégias de transformação e ressignificação de espaços.

No capítulo II, Projetos de intervenções e ações em Sena Madureira, discuto sobre a importância da Intervenção Urbana no município de Sena Madureira, destacando alguns trabalhos realizados pela artista local Núcia Sabóia.

Já no capítulo III, Colocando na Prática o conhecimento adquirido em Sena Madureira, discorro sobre minha experiência na realização de dois trabalhos artísticos, sendo um intervenção urbana e o outro uma instalação. Destaco também a maneira como o público externo reagiu, quando do contato com as produções. 


\section{CAPÍTULO I - INTERVENÇÃO URBANA: UMA FORMA DE INTERAÇÃO DO SER HUMANO COM A ARTE}

A Intervenção Urbana é uma manifestação artística que pode proporcionar várias discussões sobre a realidade exterior percebida e determinadas demandas sociais, seja para questionar, criticar ou até mesmo contemplar a arte. No Brasil, no final de 1970, a Intervenção Urbana surgiu como uma forma de expressão artística que redesenhava os espaços citadinos, por meio de performances e instalações, e deslocava o olhar do sujeito observador para outros espaços além dos museus e galarias.

Wagner Barja (2008) aborda a Intervenção Urbana enquanto uma arte de inventar e intervir nos espaços urbanos. Destaca essa linguagem como uma forma de manifestação que surge de forma diversa dentro da perspectiva da arte contemporânea e que caracteriza-se pela liberdade de atuação do artista. Podese dizer que a intervenção urbana ultrapassou fronteiras da arte, colocando o artista a questionar a própria linguagem artística, integrando-a como parte da vida cotidiana. Assim,

\footnotetext{
Partindo desses pressupostos, passa-se a entender a arte da intervenção urbana como uma manifestação que vem abarcar com a transversalidade dessa rede de conceitos, que brotam em campos de dimensões diversas e variáveis muito abrangentes no ambiente da cultura artística contemporânea. (BARJA, 2008 p. 2).
}

No final da década de 1970, começaram a surgir Intervenções com novas estratégias, com o intuído de atingir diretamente ao público, com propostas artísticas, como a do grupo artístico 3nós3.

O grupo 3nós3 incorporou novas linguagens, como happenings e as Instalações, rompendo com os limites da arte. O grupo realiza ações que questionam os espaços da cidade de São Paulo de 1979, ano em que o grupo é fundado, até 1982 . 
Podemos destacar alguns artistas que são considerados precursores da Intervenção e que realizaram trabalhos artísticos de grande relevância no Brasil, dentre eles: Hélio Oiticica (1937- 1980), Lygia Clark (1920-1988), Cildo Meireles (1948), Artur Barrio (1945), Paulo Bruscky (1949), Grupo 3nós3, Dante Velloni (1954), Flávio de Carvalho. Abaixo, duas imagens de intervenções: uma de Artur Barrio e a outra do Grupo 3nós3.

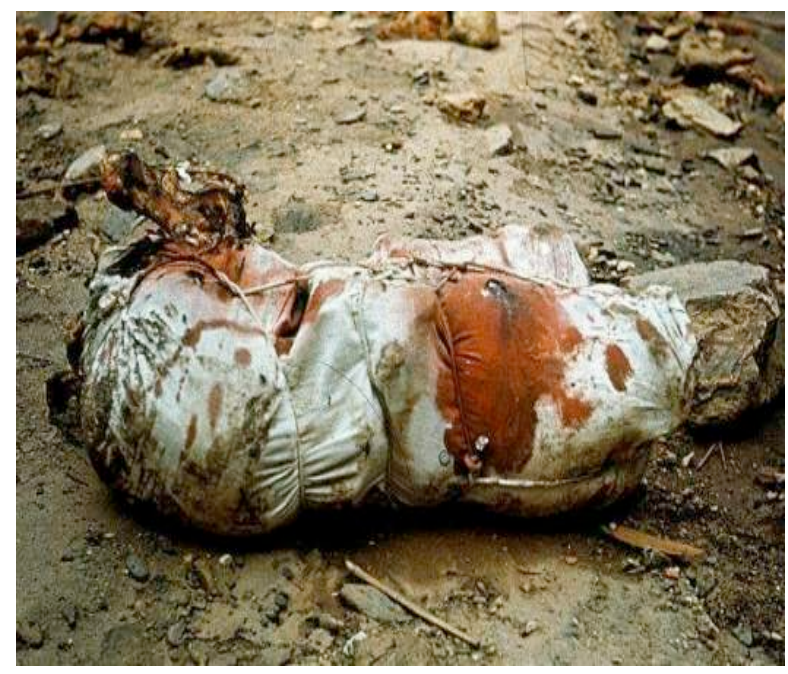

Figura 1: Intervenção urbana que causou grande impacto, de Artur Barrio (1969) Fonte: https://blogparadoxo.wordpress.com/2014/10/17/intervencoes-urbanas/

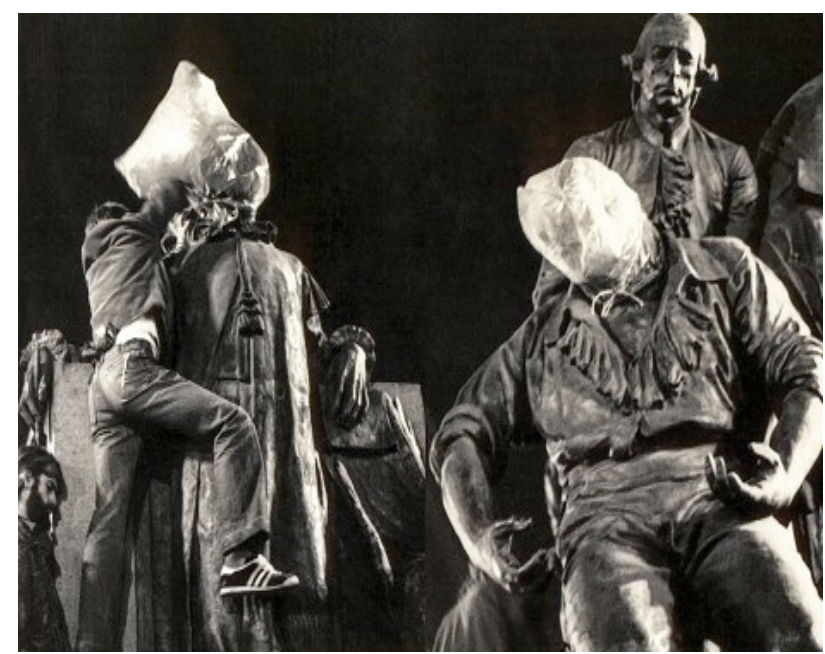

Figura 2: Ensacamento, do Grupo 3nós3 (1979)

Fonte: https://blogparadoxo.wordpress.com/2014/10/17/intervencoes-urbanas/ 
Muitos artistas aderiram à linguagem da Intervenção Urbana e desenvolveram trabalhos práticos levando as pessoas à reflexão sobre inúmeras questões sociais. Tais trabalhos proporcionam participação direta ou indireta do espectador, tornando a arte mais acessível ao público. Nesse sentido, enquanto mais acessíveis, mais pessoas terão contato com arte, o que terá como desdobramento mais sensibilidade, conscientização e difusão do conhecimento, tornando-o mais democrático.

Destaco aqui uma artista brasileira que seus trabalhos são reconhecidos internacionalmente, Lygia Clark, com a Intervenção Bichos e a performance Divisor de 1968, conforme demonstra as imagens abaixo.

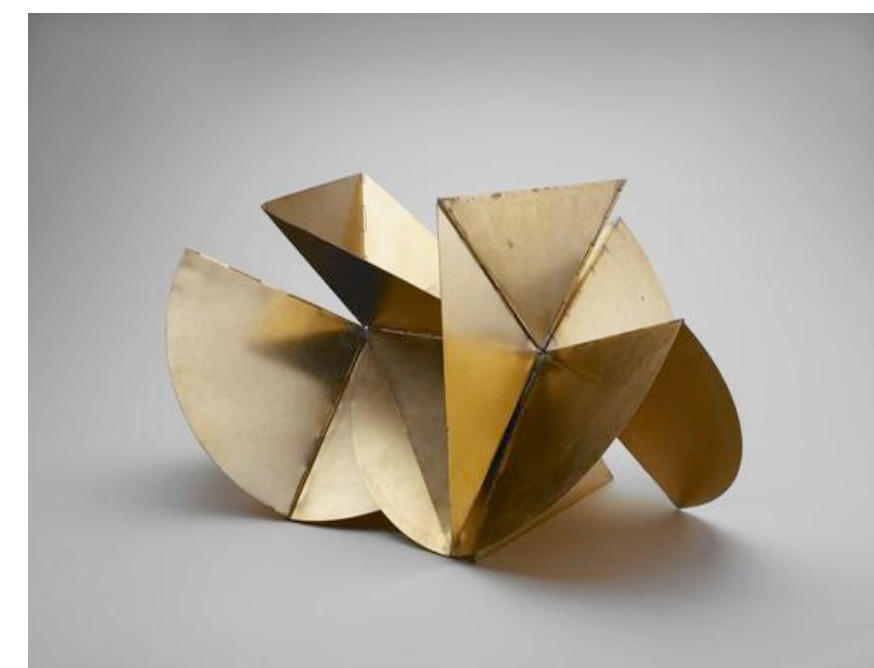

Figura 3: Bicho (Máquina),1962, de Lygia Clark

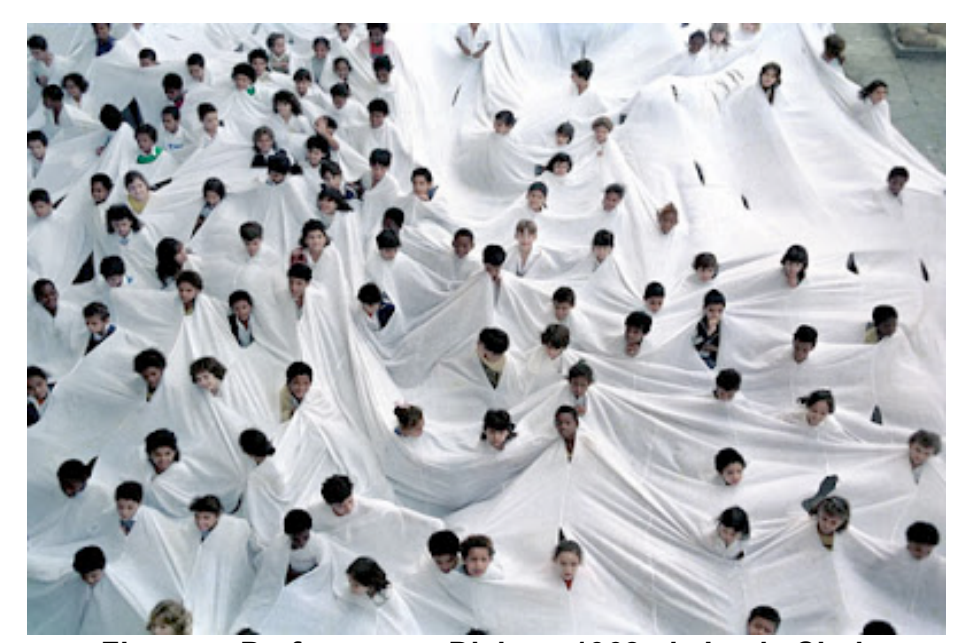

Figura 4: Performance Divisor, 1968, de Lygia Clark

Fonte: http://artfixx.blogspot.com.br/ 
Destaco também a arte de Cildo Meireles, um dos artistas mais reconhecidos e um dos mais importantes artistas brasileiros contemporâneos. O mesmo fez sua primeira instalação, O desvio para o vermelho, no museu de Arte Moderna do Rio de Janeiro (MAM/RJ), em 1967, que proporcionou uma série de sensações e interpretações no espectador.

Figura 5: Desvio para o Vermelho, de Cildo Meireles, 1967-84,

Fonte: http://www.inhotim.org.br/inhotim/arte-contemporanea/obras/desvio-para-o-vermelho-i-impregnacao-iientorno-iii-

Os trabalhos do artista são pioneiros no campo da Instalação, por sua diversidade de materiais, técnicas e suportes, mostrando em seus trabalhos artísticos questões de natureza política e social.

Os artistas que me inspiraram a fazer este trabalho monográfico foram Bohyun Yoon, Eduardo Srur e Banksy. Este último é um artista de rua conhecido mundialmente. Em um de seus trabalhos artísticos, o artista fez uma instalação, The Siren of the Lambs (A Sirene dos Cordeiros), uma obra artística móvel em que o artista usa um caminhão carregando animais de pelúcia, com movimentos e sons de animais para chamar a atenção às condições de maus tratos em que os animais são transportados para as fazendas, e aos abatedouros onde serão mortos para servir de alimentação para as pessoas. 


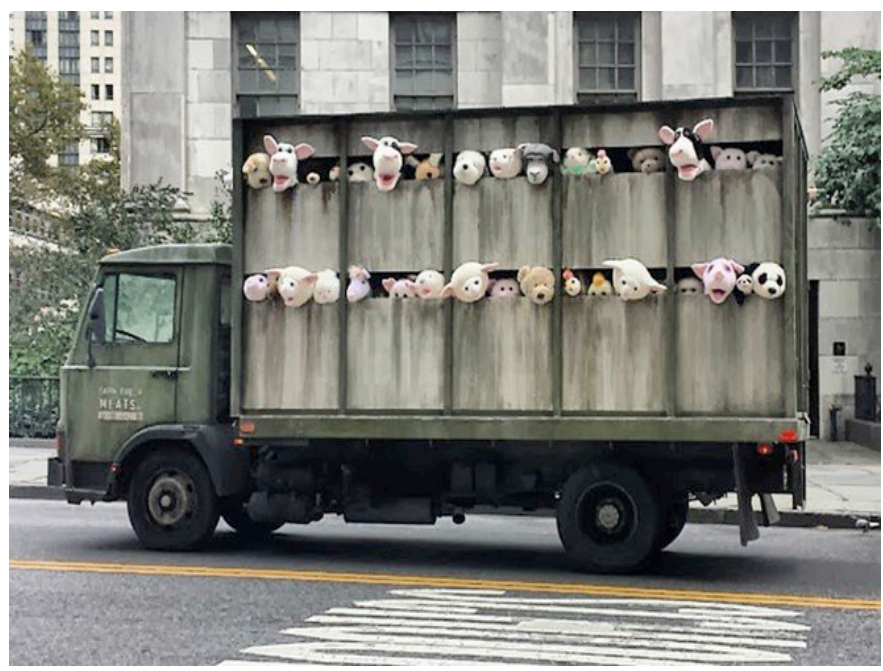

Figura 6: Banksy / TreeHugger

Fonte: https://www.anda.jor.br/2013/10/banksy-bichos-pelucia-denunciar-sofrimento-animais/

Outro artista que chama a atenção em seus trabalhos é Bohyun Yoon, um sul-coreano que estudou no Japão. Seus trabalhos investigam as imagens do corpo humano em termos de identidade, sexualidade, gênero e cultura; também explora os limite do corpo e os limites da comunicação. Esse artista usa uma ampla gama de materiais em seus trabalhos, incluindo vidro, espelho, vinil, através de gêneros, performances, instalações e vídeos.

Em uma de suas instalações, o mesmo se utiliza de vários pedaços fragmentados de bonecos suspensos, criando sombras através dos fragmentos. O efeito é bastante interessante, as partes dos bonecos estão separadas, porém, com o efeito das luzes, as unem formando o corpo humano.

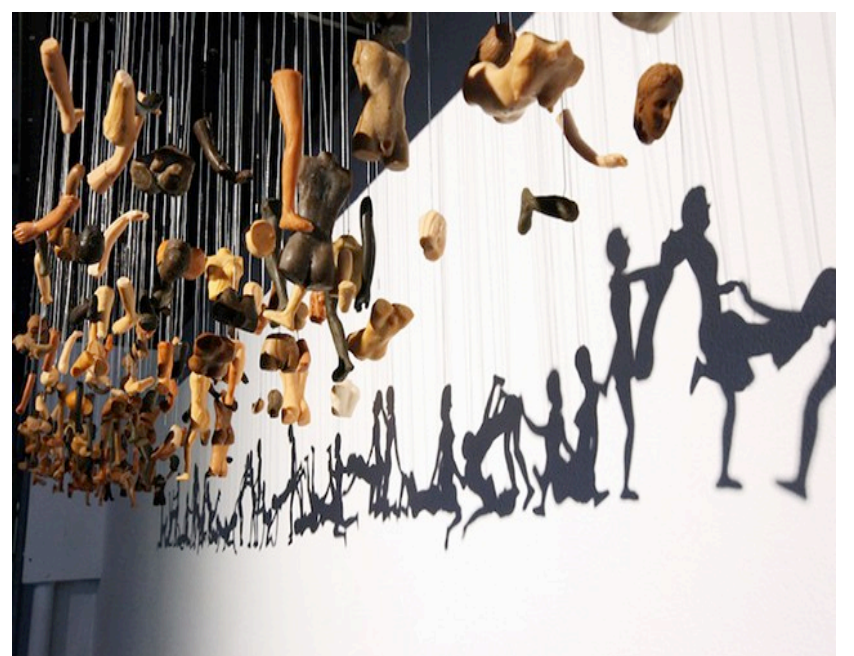

Figura 7: A "Unidade" Sensual de Bohyun Yoon 1 Fonte: https://inspi.com.br/2013/04/unity-bohyun-yoon/ 


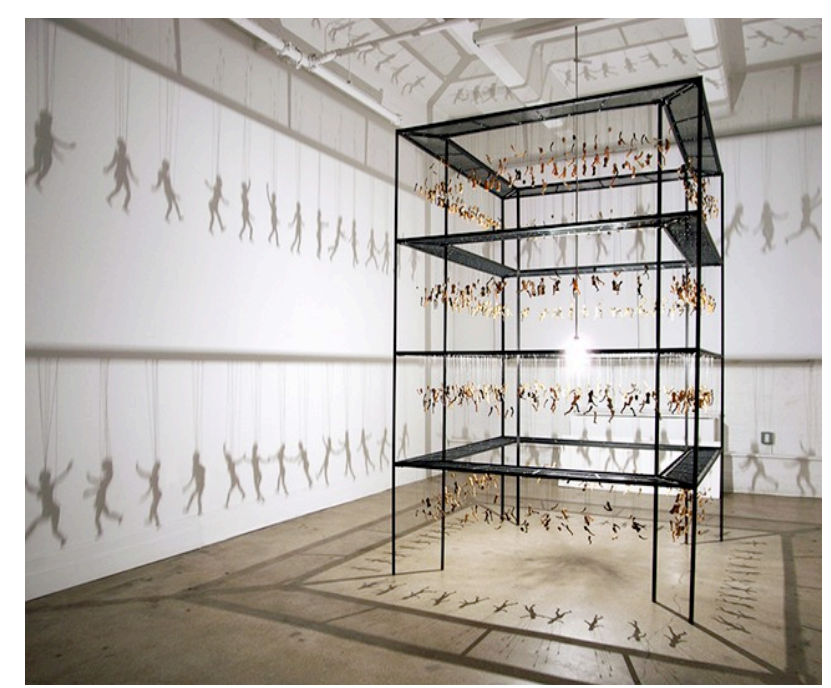

Figura 8: A "Unidade" Sensual de Bohyun Yoon 2 Fonte: https://inspi.com.br/2013/04/unity-bohyun-yoon/

Eduardo Srur, nascido em 1974, na cidade de São Paulo, é outro artista que se destacou na Intervenção Urbana. O artista utiliza o espaço público para desenvolver suas obras, chamando assim a atenção para questões ambientais e o cotidiano nas metrópoles, levando a arte até a sociedade e aproximando-a da vida das pessoas.

O artista utiliza a cidade de São Paulo como sendo um laboratório de pesquisa, onde realiza suas manifestações e onde se expressa artisticamente com críticas e reflexões. Suas intervenções contribuem para que as pessoas enxerguem a realidade de outra forma, rompendo com a zona de conforto, por meio da mudança do olhar e do pensamento.

$\mathrm{O}$ artista fez uma Intervenção muito marcante, em que reuniu garrafas PETs gigantes e coloridas espalhadas pelo Rio Tietê. Ele buscou atrair o olhar das pessoas para a agressão contra o Rio, extremamente poluído. 


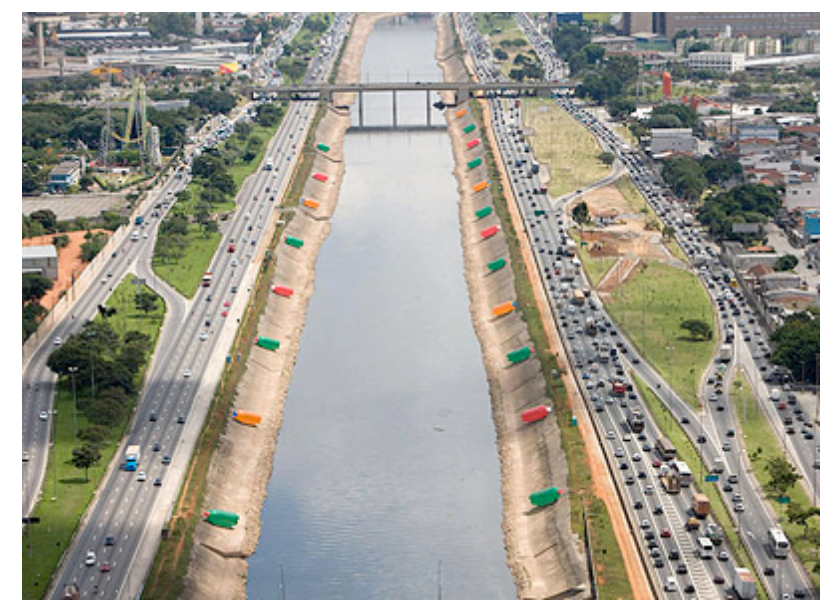

Figura 9: Pets gigantes nas margens do rio Tietê Fonte: Itaú Cultural

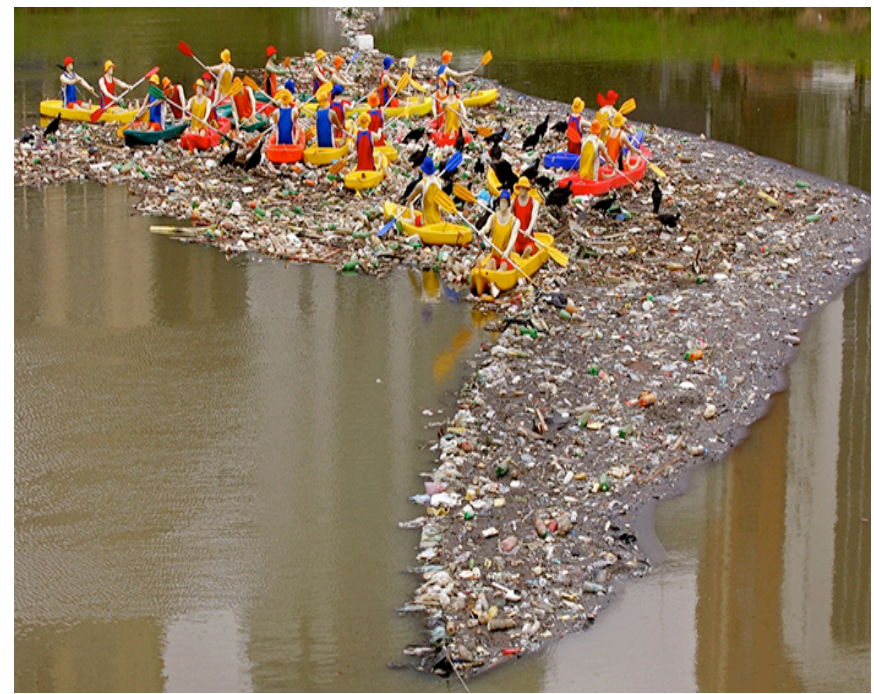

Figura 10: Intervenção 'Caiaques' no rio Pinheiros

Fonte: http://oviajante.uol.com.br/intervencoes-urbanas-mudam-a-cara-das-cidades/>. Acesso em 16 de outubro de 2017 


\section{CAPÍTULO II - PROJETOS DE INTERVENÇÕES E AÇÕES EM SENA MADUREIRA}

A Intervenção Urbana é uma linguagem que pode transformar lugares que passam despercebidos no nosso dia a dia, com o propósito de transmitir mensagens e também poder questionar e transformar a vida cotidiana, o que aguça a curiosidade nas pessoas que estão acostumadas a ver a arte apenas em lugares fechados como nas galerias e museus, como é o caso no município de Sena Madureira. Nesse sentido, sentimos a necessidade de divulgar e realizar trabalhos artísticos voltados para essa linguagem que não é tão conhecida no município.

No município de Sena Madureira, a "artista" local Núcia Sabóia foi uma das primeiras a desenvolver trabalhos artísticos utilizando-se da linguagem da Intervenção Urbana e Instalações em alguns pontos da cidade.

Existem diferentes tipos de intervenção Urbana e, dentre elas, a Instalação Artística atrai e causa certo impacto ao público apreciador que interage diretamente com a obra.

Dentre os trabalhos realizados por Núcia Sabóia, destacam-se uma Instalação Artística que retrata a questão da violência contra a mulher. Para tal, a artista utilizou calcinhas de diferentes tamanhos na Praça Arlindo Figueiredo, no município de Sena Madureira, com intenção de chamar a atenção para a violência contra a mulher. A artista relata que a Instalação provocou reações diversas ao público apreciador, como estranhamento e até mesmo surpresa.

Para começar a embasar minha pesquisa, relato a experiência dessa arte educadora, que foi quem trouxe a linguagem Intervenção Urbana para o público de Sena Madureira, através de algumas intervenções e instalações feitas pela cidade. Núcia Sabóia Ferreira (2012, p. 8) apresenta o trabalho da 
Intervenção Urbana como uma linguagem artística para o ensino não formal de Sena Madureira, no Acre. A principal motivação deste trabalho surgiu da necessidade de divulgar uma linguagem artística que não é tão conhecida na comunidade de Sena Madureira.

No município de Sena Madureira existe grande carência em relação à produção das artes, visto que as poucas formas de produção artística existente na localidade são, em sua maior parte, limitadas a locais restritos e a um pequeno público, pois nem todas as pessoas desenvolveram o gosto pela apreciação à arte. Desta forma, as pessoas da comunidade que manifestam o interesse por artes podem ter acesso às produções artísticas, normalmente, visitando obras deixadas pelos índios em um museu local - um pequeno museu que registra e abriga muito pouco sobre a arte e história da cultura local.

Segundo Núcia Sabóia Ferreira (2012, p. 8),

As pessoas estão acostumadas com a arte em locais próprios para sua exposição, como museus, galerias e outros espaços que não permitem uma maior aproximação do público com as obras. Entretanto, a cidade de Sena Madureira não dispõe de espaços de exposição de arte. Assim, com intervenção nos espaços públicos, além de permitir a interação entre os espectadores e a obra de arte, também estimula novas formas de manifestação da arte, podendo dar visibilidade aos artistas locais.

E diz, ainda, que

A intervenção urbana, em linhas gerais, é uma linguagem artística que permite estabelecer, em um espaço público, uma interação direta entre sociedade e o sujeito, podendo transformar o cotidiano, o contexto sociocultural e o próprio espaço. Enquanto espaço de produção e exposição da arte, impacta nos espectadores e na sociedade em geral, porque permite que qualquer pessoa, ao transitar por ele, seja desafiada a mergulhar no mundo artístico. As intervenções podem transformar a forma de vermos e fazermos arte. (FERREIRA, 2012, p. 8).

Os trabalhos da artista Núcia Sabóia são bastante interessantes, os quais nos chamam a atenção para a instalação, que é um tipo de intervenção 
muito atrativo ao público, por ser provocativo e ter a participação do público. A referida artista, conforme mencionado, realizou, no município de Sena Madureira, uma instalação em que utiliza várias calcinhas de diferentes tipos e formatos penduradas em barbantes e expostas em um muro, com o intuito de fazer referência à violência contra a mulher.

Para a artista,

Essa prática artística nos permite produzir livremente nossos trabalhos artísticos expressando nossas manifestações, o que não significa que seja algo tão simples. É um trabalho que requer cautela, cuidado e envolvimento tanto em relação aos propósitos estéticos quanto aos aspectos sociais, culturais e também políticos envolvidos. Afinal, a linguagem intervém em espaços coletivos e urbanos normalmente bastante frequentados, muitas vezes provoca "tumultos" em prédios, praças, parques, alterando a rotina de um bairro ou uma cidade, em uma sociedade tão regida por normas políticas e pelo poder público. (FERREIRA, 2012, p. 8).

Abaixo algumas imagens da instalação:

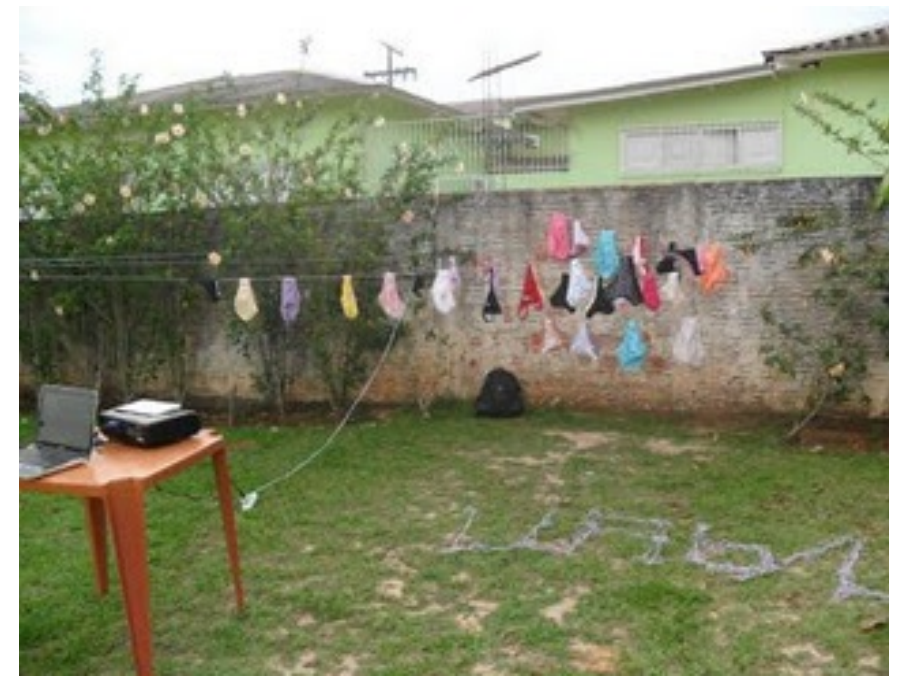

Figura 11: Instalação feita na Praça Arlindo Figueiredo 1 Fonte: Arquivo pessoal de Núcia Sabóia 


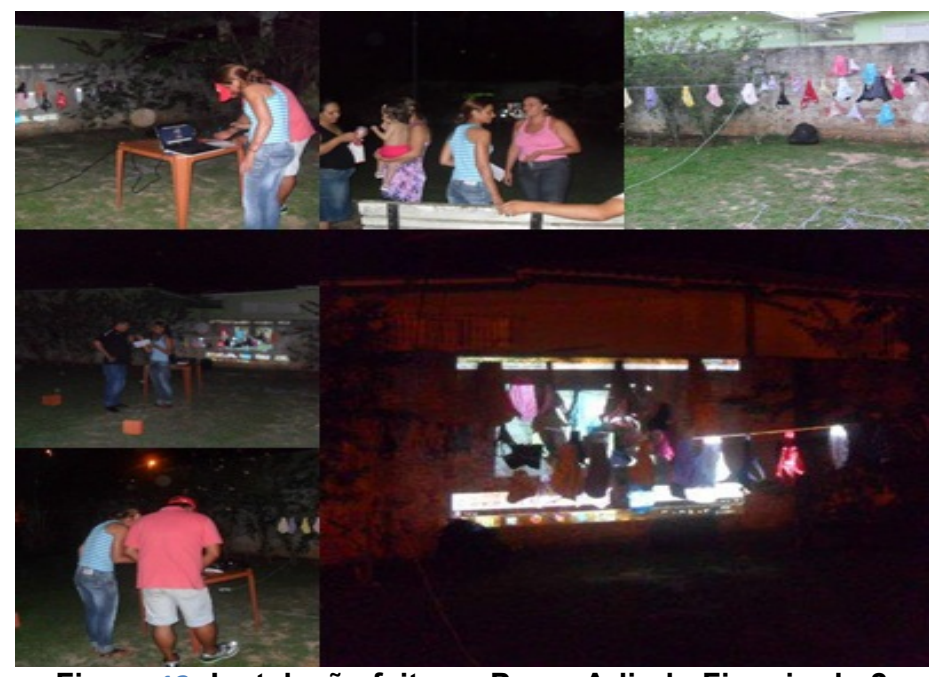

Figura 12: Instalação feita na Praça Arlindo Figueiredo 2 Fonte: Arquivo pessoal de Núcia Sabóia

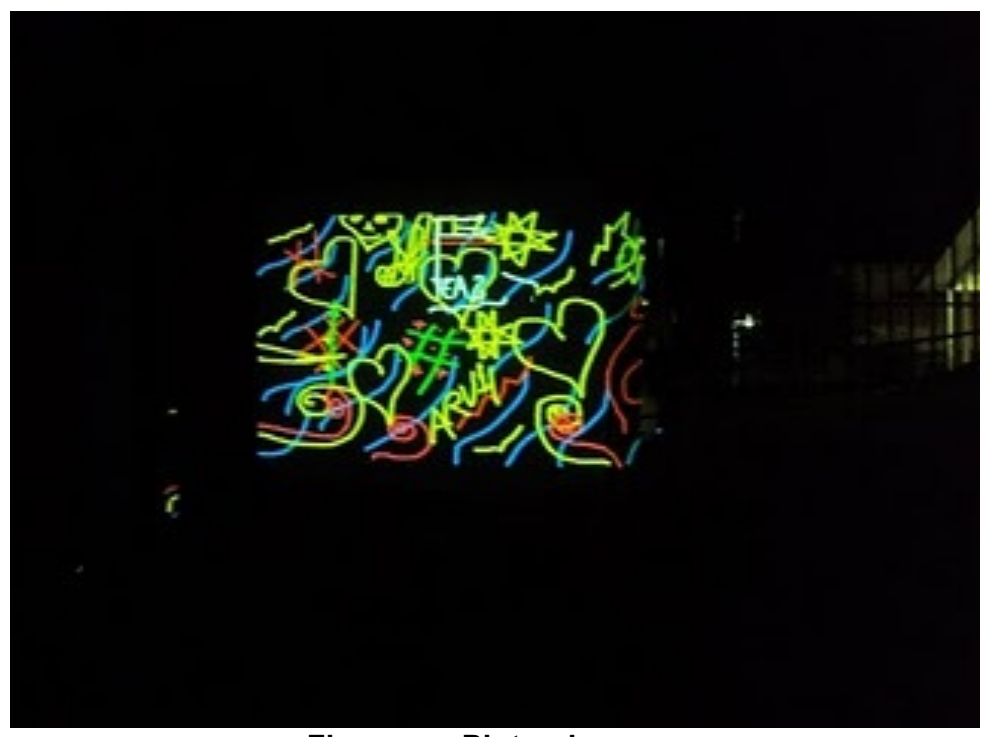

Figura 13: Pintando muro

Fonte: Arquivo pessoal de Núcia Sabóia 


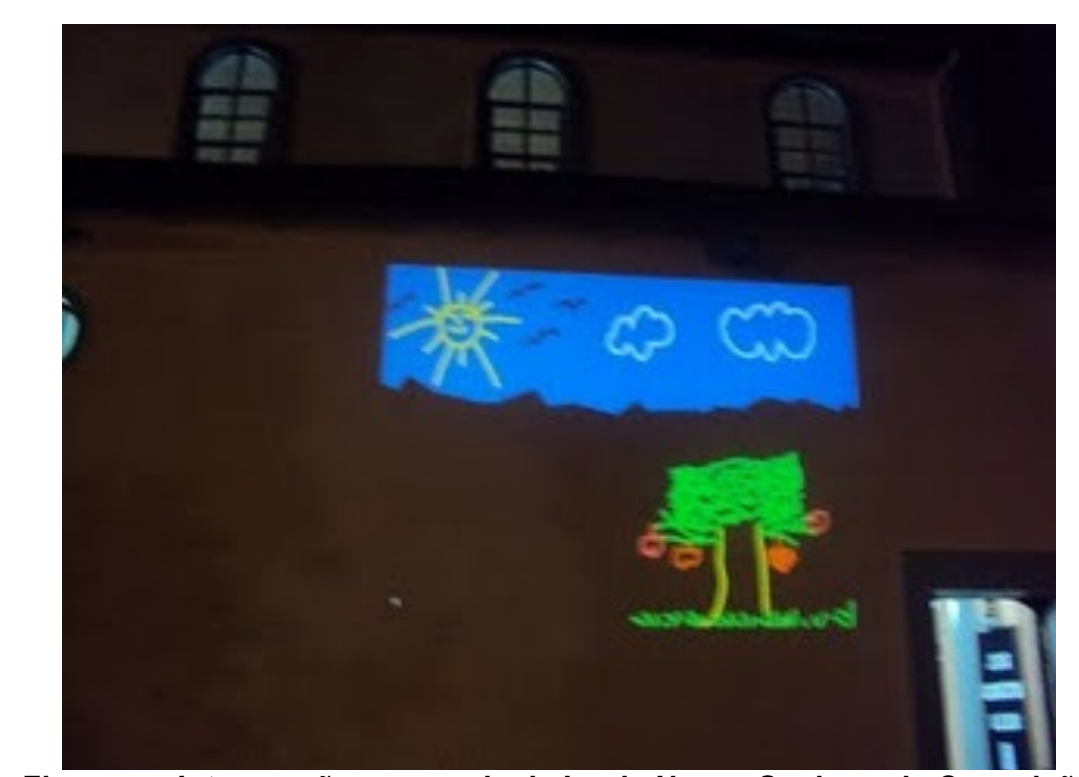

Figura 14: Intervenção na parede da Igreja Nossa Senhora da Conceição Fonte: Arquivo pessoal de Núcia Sabóia

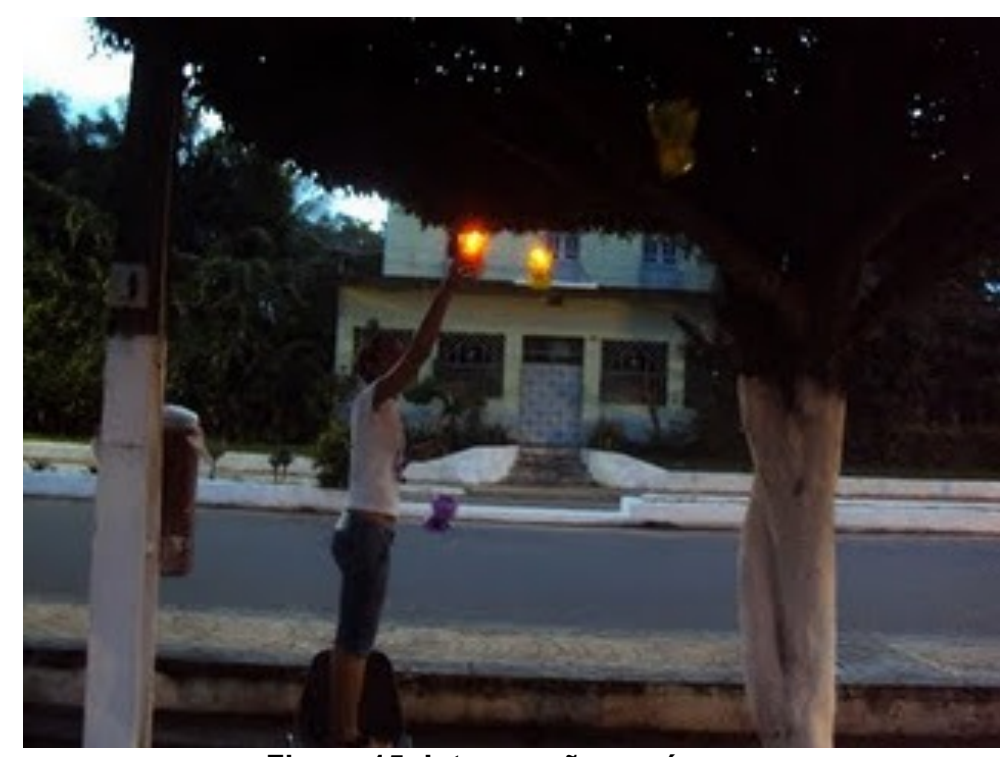

Figura 15: Intervenção em árvore

Fonte: Arquivo pessoal de Núcia Sabóia

O município de Sena Madureira foi palco do projeto Interações Não Distantes. No referido projeto, a artista Íris Helena, junto com alunos e ex-alunos de Artes Visuais, fizeram uma ODE à SENA, onde realizaram varias intervenções com a finalidade de homenagear o município.

Foram várias ações praticadas pelo projeto Interações Não Distantes, dentre elas a confecção de um postal com a frase: "estive em Sena Madureira e 
lembrei de você". No final do projeto, foi criada a lei de contemplação. Ficou definido que dia 09 de agosto será eternamente o dia de com afeto e carinho à cidade de Sena Madureira.

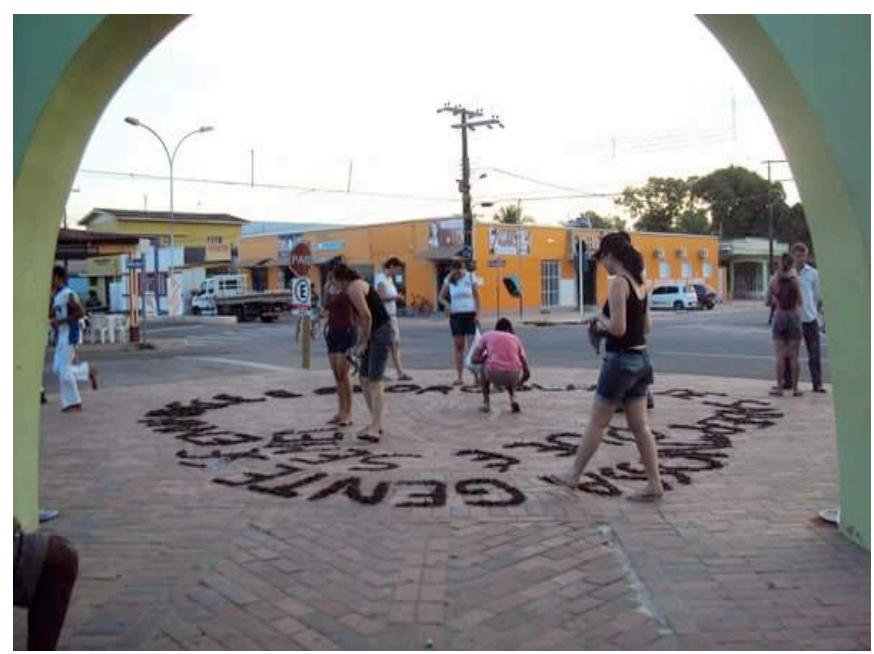

Figura 15: Interações Não Distantes 1 Fonte: Arquivo pessoal de Núcia Sabóia

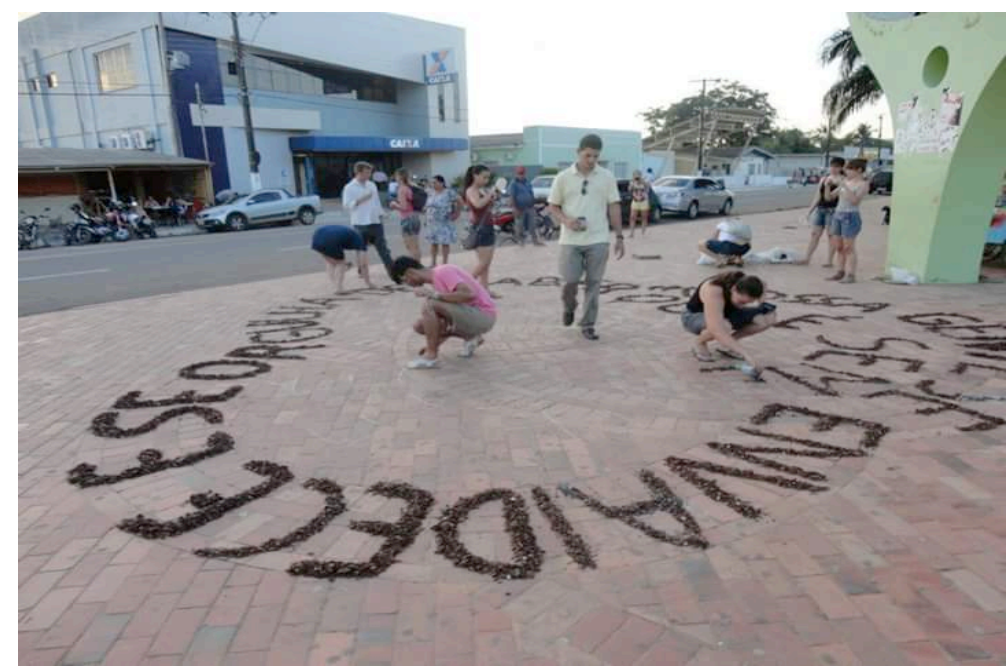

Figura 16: Interações Não Distantes 2 Fonte: Arquivo pessoal de Núcia Sabóia 


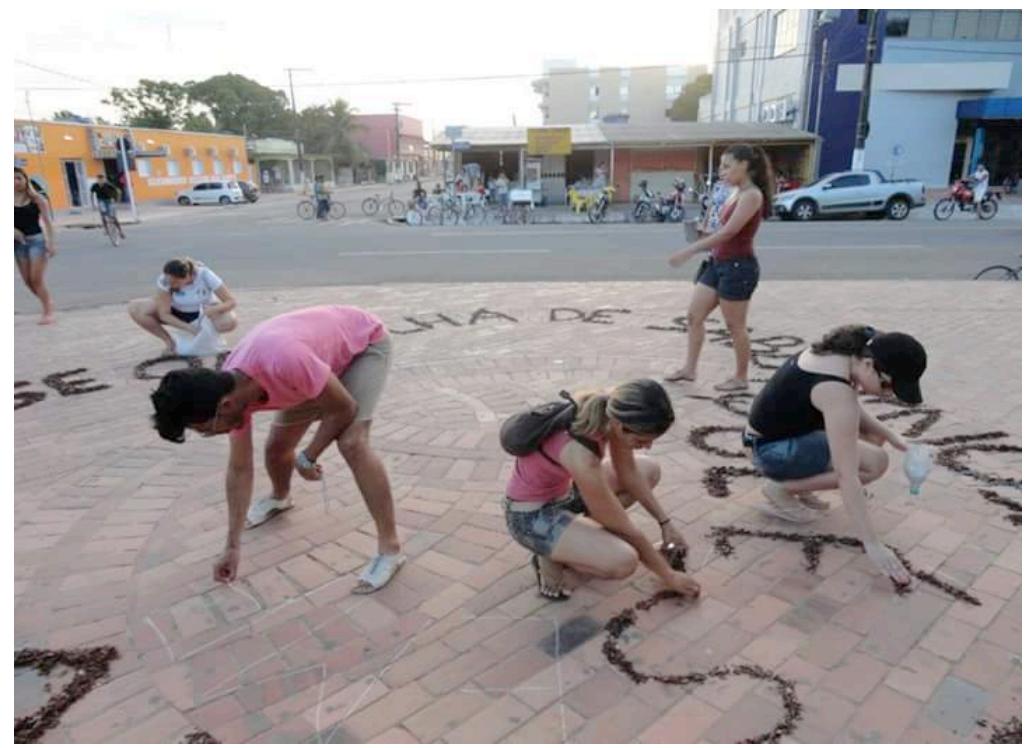

Figura 17: Interações Não Distantes 3

Fonte: Arquivo pessoal de Núcia Sabóia

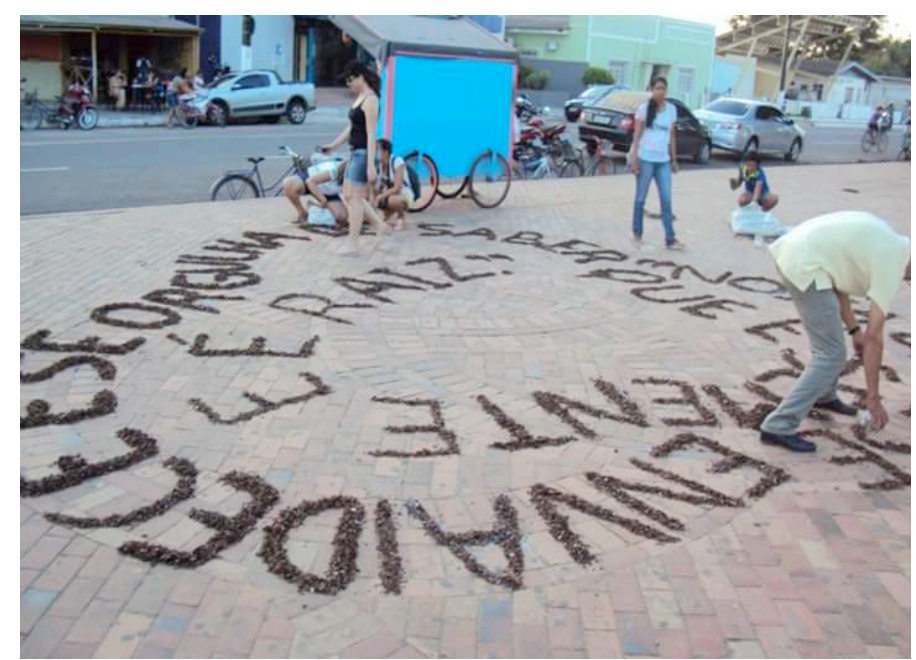

Figura 18: Interações Não Distantes 4 Fonte: Arquivo pessoal Núcia Sabóia 


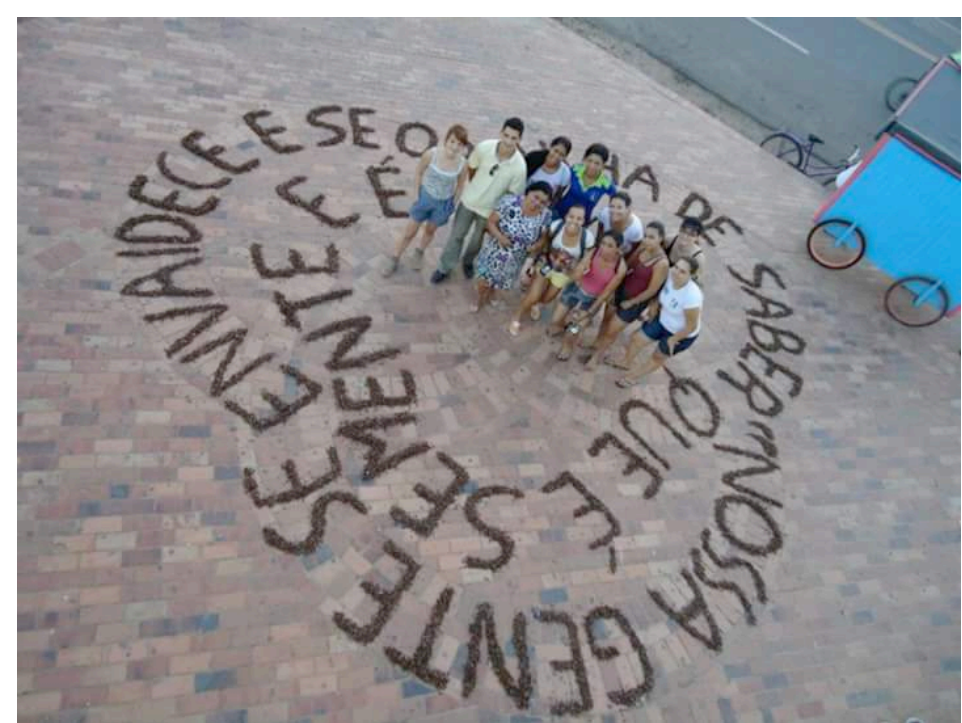

Figura 19: Interações Não Distantes 5

Fonte: Arquivo pessoal Núcia Sabóia 


\section{CAPÍTULO III - COLOCANDO NA PRÁTICA O CONHECIMENTO ADQUIRIDO EM SENA MADUREIRA}

\subsection{Intervenção Urbana}

Foi partindo dessa perspectiva da Intervenção Urbana que realizei uma Intervenção em Sena Madureira, inspirada no artista Eduardo Srur, cujos trabalhos são realizados em áreas centrais das cidades, e que consiste em uma interação com um objeto artístico previamente existente, por exemplo, um monumento, uma ação, uma pintura, mural em um espaço público, visando colocar em questão as percepções acerca do objeto artístico onde foi possível modificar o espaço urbano ao nosso redor, de maneira que isso intervenha no cotidiano, e a interação com essa linguagem venha modificar o olhar que temos sobre alguma paisagem.

Conforme as imagens abaixo, diante de um tronco de uma árvore cortada pôde-se fazer uma pintura simbolizando a árvore que foi destruída, e dentro da projeção uma mensagem à sociedade, para que todos que ali passassem pudessem curiosamente apreciar e ler, e, talvez, se conscientizar acerca da importância que há em plantar, cultiva e cuidar do nosso meio ambiente, nossas árvores, a natureza como num todo. 


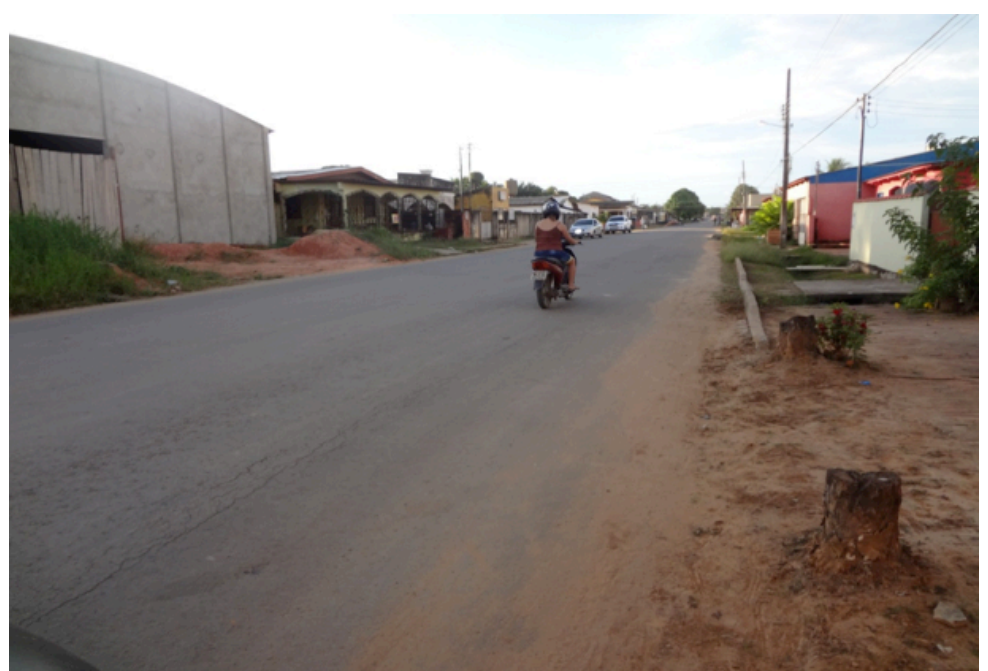

Figura 20: Intervenção sobre meio ambiente 1

Fonte: Arquivo pessoal de Gerliana Cavalcante Neres

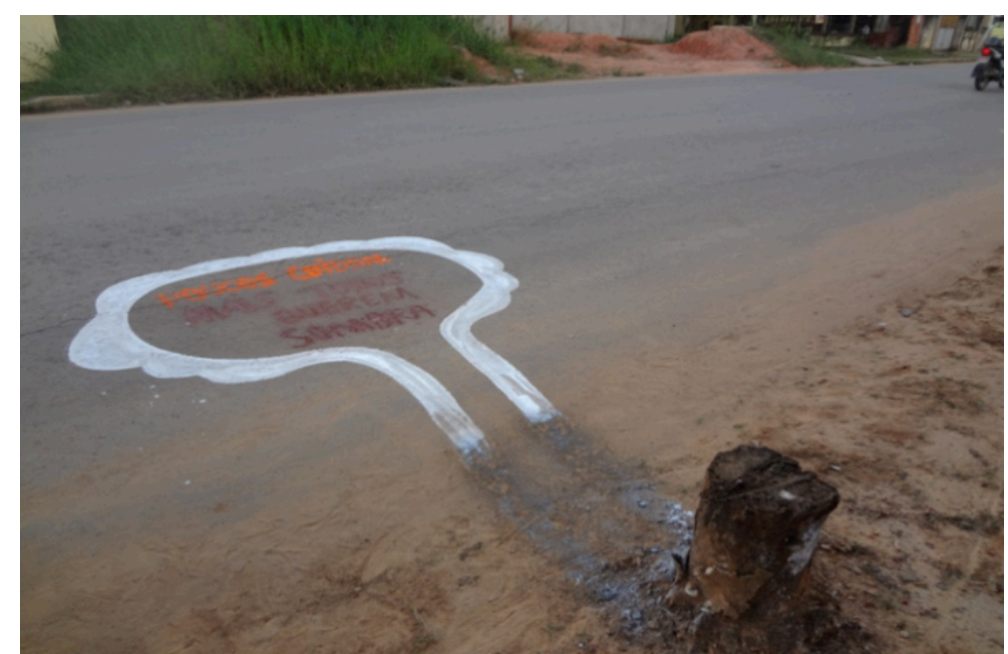

Figura 21: Intervenção sobre meio ambiente 2 Fonte: Arquivo pessoal de Gerliana Cavalcante Neres 


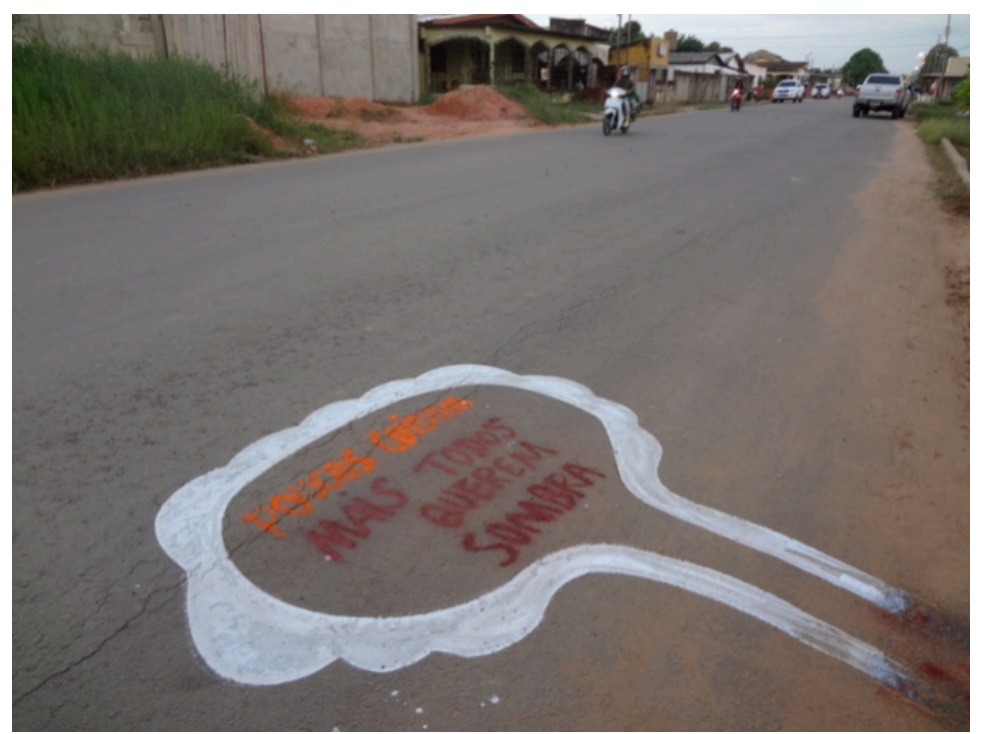

Figura 22: Intervenção sobre meio ambiente 3

Fonte: Arquivo pessoal de Gerliana Cavalcante Neres

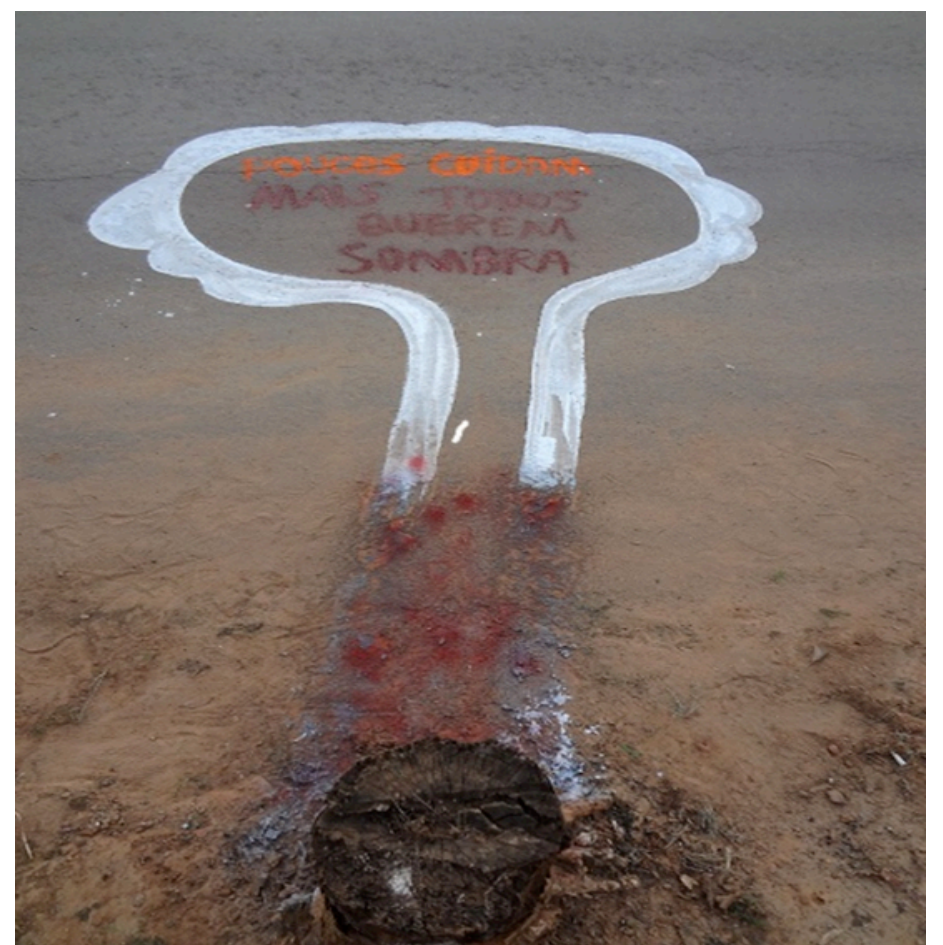

Figura 23: Intervenção sobre meio ambiente 4 Fonte: Arquivo pessoal de Gerliana Cavalcante Neres 


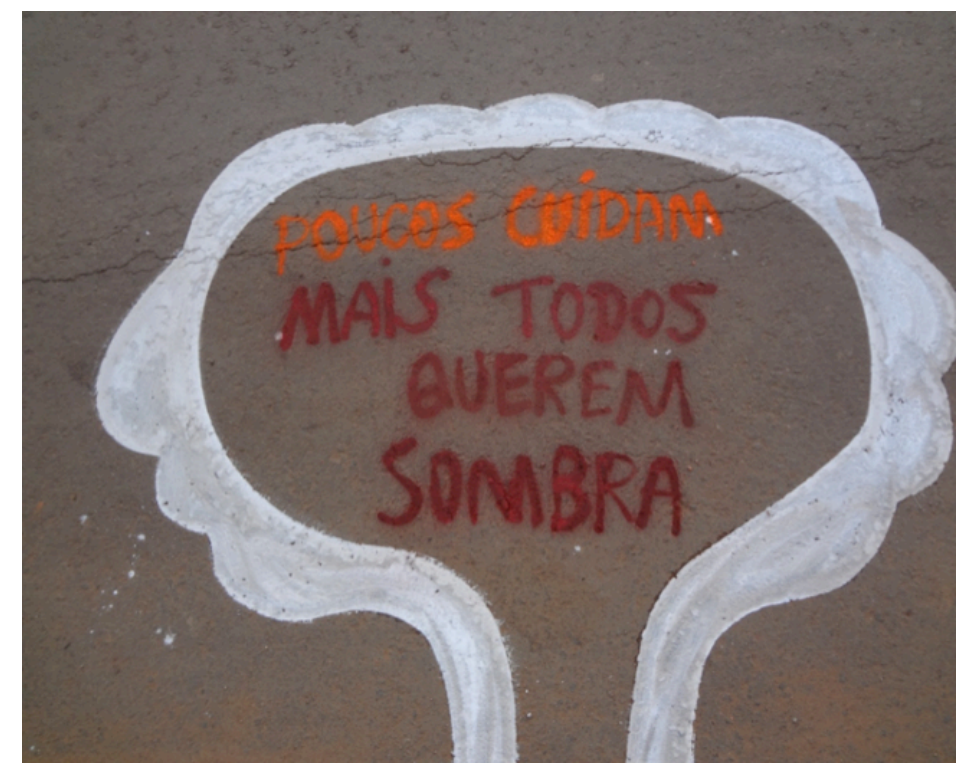

Figura 24: Intervenção sobre meio ambiente 5

Fonte: Arquivo pessoal de Gerliana Cavalcante Neres

Projetos de intervenções sobre meio ambiente são de extrema importância, em nossa contemporaneidade, visto que nossa qualidade de vida tem sido demasiadamente afetada pelo desmatamento, poluição e exploração irresponsável da natureza. Acredito que o artista tem papel fundamental no processo de conscientização social sobre os vários problemas que afetam a vida das pessoas, dentre eles a degradação do meio ambiente.

\subsection{Instalação no Espaço Público}

A Instalação é uma linguagem contemporânea, são obras criadas para despertarem inquietação em quem caminha pelo local, e tais instalações representam um momento, uma realidade, ou um acontecimento exato e específico da sociedade. Partindo dessa suposição, produzi uma instalação que foi exposta em um lugar público perto de minha residência, dentro de um parque florestal, onde o tráfego de pessoas é muito intenso durante o dia.

Um dos assuntos trabalhados nas instalações urbanas que fiz foi 0 abuso sexual infantil. Segundo Naura Liane de Oliveira Aded et al. (2006, p. 204), o abuso sexual em crianças e adolescentes é uma das formas de violência mais danosas, que ocorre desde a Antiguidade, "porém pouco se 
avançou no sentido de prevenir e amenizar suas consequências. Diferenças culturais, legais e de procedimentos dos profissionais envolvidos talvez expliquem a dificuldade em se estabelecer políticas públicas de prevenção e enfrentamento do problema no mundo inteiro". Esse tipo de violência não conhece fronteiras geográficas e nem sociais, ocorre no mundo inteiro e em qualquer classe social, e tem acarretado inúmeros problemas emocionais, psicológicos e sociais em inúmeras pessoas que passaram por essa experiência traumática. No Brasil, o número de crianças e adolescentes vítimas de abuso sexual é alarmante. Segundo as estatísticas, "em 2015 e 2016, 37 mil casos de denúncias de violência sexual na faixa etária de 0 a 18 anos foram recebidos pelo Disque 100" (BRASIL, 2017, online). Tendo em vista os graves impactos psicológicos e sociais que essa prática tem sobre as vítimas e suas famílias, alguns artistas têm retratado esse tipo de violência em obras de arte, por meio de performances, instalações e intervenções urbanas, com o fito de sensibilizar e conscientizar a população sobre esse problema social. Nesse sentido, a arte age no sentido de humanizar as pessoas, para que possamos viver em uma sociedade mais harmoniosa, onde os direitos humanos sejam respeitados.

Todo o material que utilizei na instalação foi exatamente pensando no intuito de poder chamar a atenção do público para a questão do abuso sexual infantil. Então, através da simbologia feita, por meio de objetos como as bonecas despidas e a construção de um cercado feito de tela, que representa as grades de uma prisão, tentei transmitir uma mensagem ao público de que o abuso infantil tem acarretado sérios problemas na vida das crianças. A cerca que representa a cela seria como se a criança estivesse presa neste mundo por um bom tempo, já a fita preta na boca das bonecas transmitem a sensação de vergonha e, mais do que isso, o medo de uma possível represália por parte de quem pratica tal crime contra estas crianças; além disso, a instalação tenta projetar a imagem de medo, isolamento, ansiedade, depressão, problemas de relação interpessoal provocada por esse tipo de violência na vida de inúmeras pessoas. 
As fitas pretas tapando as bocas das bonecas transmite a sensação de silêncio destas crianças, também é uma mensagem a todos nós cidadãos que não podemos ficar calados diante de uma situação dessa natureza e gravidade, temos que denunciar todo e qualquer tipo de abuso e maus tratos direcionados às crianças, na tentativa de preservar seus direitos.

Sabemos que o número de crianças e adolescente abusados no Brasil é cada vez maior, mas só uma minoria apresenta queixa. Isso tudo se dá devido ao trauma psicológico causados nessas pessoas e em suas famílias.

Diante dessa situação, a arte educação tem também papel no combate ao abuso sexual infantil, por meio de produções artísticas que sensibilizem e conscientizem a sociedade a denunciar esse ato desumano, na tentativa de construir uma sociedade mais justa. Foi nessa perspectiva, que produzi uma instalação urbana, conforme mostra as imagens a seguir:

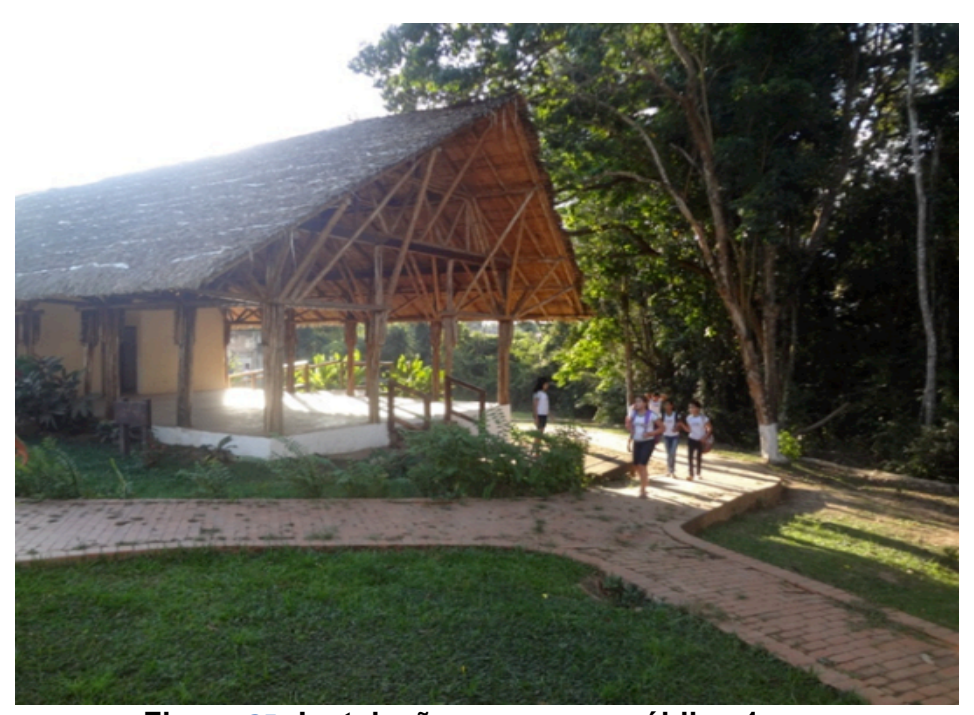

Figura 25: Instalação no espaço público 1

Fonte: Arquivo pessoal de Gerliana Cavalcante Neres 


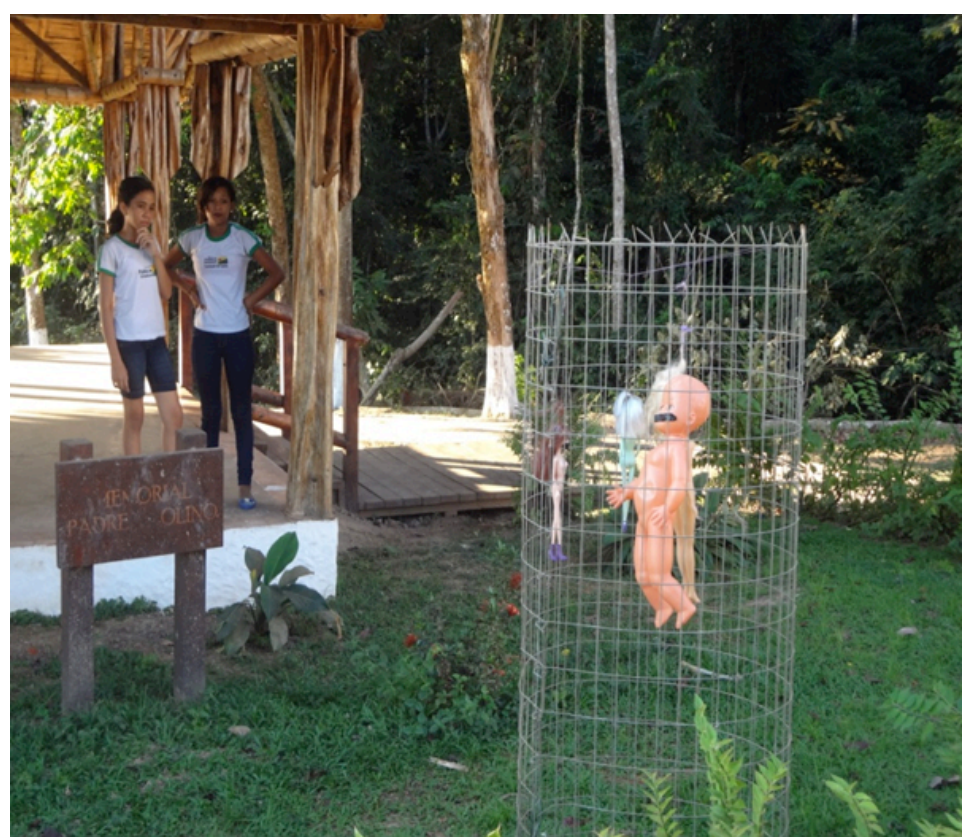

Figura 26: Instalação no espaço público 2

Fonte: Arquivo pessoal de Gerliana Cavalcante Neres 


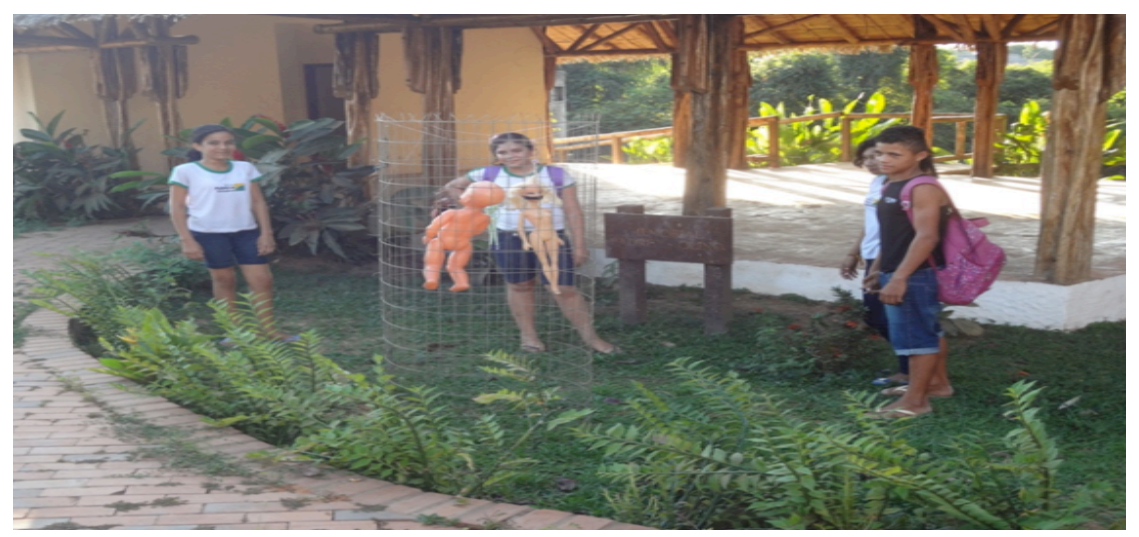

Figura 27: Instalação no espaço público 3

Fonte: Arquivo pessoal de Gerliana Cavalcante Neres

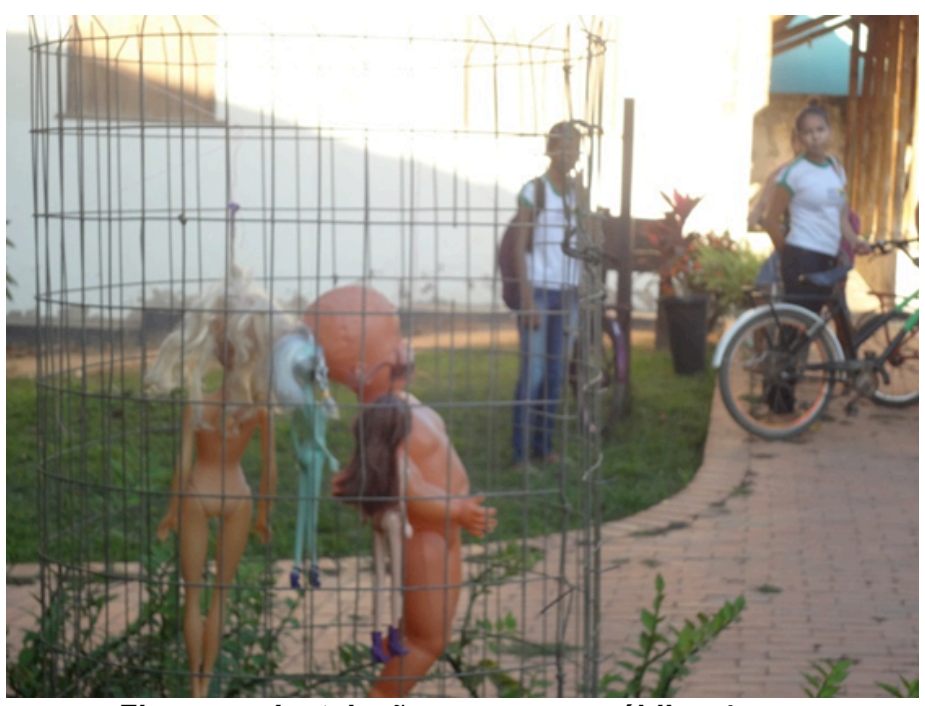

Figura 28: Instalação no espaço público 4

Fonte: Arquivo pessoal de Gerliana Cavalcante Neres 


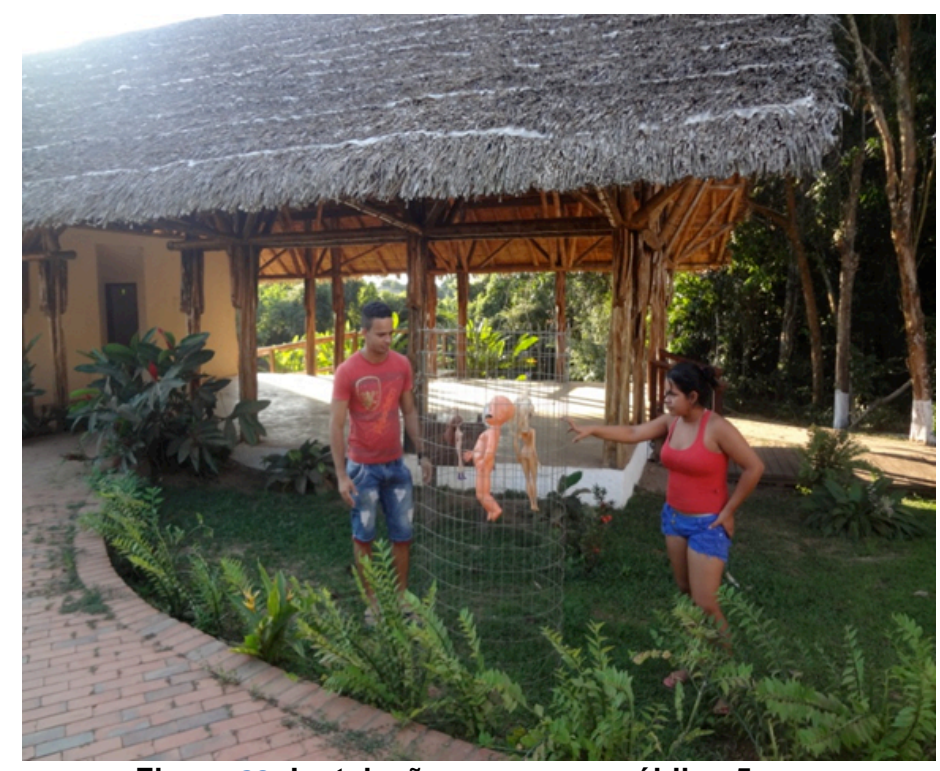

Figura 29: Instalação no espaço público 5

Fonte: Arquivo pessoal de Gerliana Cavalcante Neres

\subsubsection{Como o público reagiu diante da obra}

Durante a Instalação, a reação do público foi de interação. Ao apreciarem a obra, notou-se a manifestação de posturas de estranheza e, ao mesmo tempo, curiosidade quanto ao significado desse ato. As pessoas se aproximavam diante da instalação, apreciavam e somente um participante do cenário perguntou sobre o que estava sendo exposto, ao passo que lhe foi explicado o significado da simbologia do ato, o que foi bom para compreensão de todos que estavam ali.

Mas, a maior parte do público somente olhou e tocou na obra e não se manifestou verbalmente sobre as impressões, o que não nos permitiu perceber quais imagens e reflexões criou-se sobre a instalação e o tema abordado.

Embora a participação do público não tenha sido muito envolvente nas indagações e reflexões, nota-se que a experiência foi construtiva e importante nesta fase do trabalho. 


\section{CONSIDERAÇÕES FINAIS}

Ao final de todo o processo, onde foi possível construir um longo trajeto no desenvolvimento deste projeto de "Intervenção Urbana", vemos que valeu muito todo o esforço e demanda, pois o tema (Intervenção Urbana) atrai muito a atenção e curiosidade das pessoas e a sociedade como um todo, visto que trabalhos desta natureza possibilitam a manifestação de várias formas de sensações e pensamentos.

Com este trabalho, pôde-se perceber que a sociedade em geral diante de cenas como as que foram apresentadas ao longo deste projeto, manifestam-se de formas diversas, pois umas aceitam bem, outras até chegam a ficarem encantadas, uns poucos não entendem, e há também aqueles que, por não compreender a dimensão significativa da arte intervenção, manifestam pensamentos em seu desfavor.

Mas, com esta modalidade de ensino não formal foi interessante para que a comunidade compreendesse que a arte está muito além de Museus e galerias.

Levar essa linguagem artística contemporânea para as pessoas foi algo muito produtivo e relevante, tanto para eles (espectadores), quanta para mim intermediadora deste projeto. Ver o público manifestar seus pensamentos seja através de um olhar, de um gesto, de um silêncio etc. é algo magnífico e prazeroso, ou seja, uma sensação de realização, pois este é o maior propósito ao se fazer um trabalho onde se pretende atrair o público, e os fazer participar de muitas formas e maneiras.

Tudo o que foi planejado e praticado nos trabalhos de intervenção teve sua devida importância, mesmo sabendo que algumas atividades não foram de grande envolvimento para alguns. Mas, de forma geral, os trabalhos de intervenção que realizei levaram as pessoas a conhecerem mais sobre manifestações artísticas que não eram acostumados a apreciar, uma 
experiência muito produtiva que contribuiu para a construção do conhecimento e aprendizado de todos os envolvidos. 


\section{REFERÊNCIAS}

ADED, Naura Liane de Oliveira; DALCIN, Luís Galluzzi da Silva; MORAES, Talvane Martins de e CAVALCANTI, Maria Tavares. Abuso sexual em crianças e adolescentes: revisão de 100 anos de literatura. Revista Psiq. Clínica, 33 (4), 2042013, 2006.

BRASIL. Dia nacional contra abuso sexual de crianças e jovens é celebrado nesta quinta (18). In: Portal Brasil, 18 de maio de 2017. Disponível em: http://www.brasil.gov.br/cidadania-e-justica/2017/05/dia-nacional-contra-abusosexual-de-criancas-e-jovens-e-celebrado-nesta-quinta-18

SCHULTZ, Valdemar. Intervenções urbanas, arte e escola: experimentações e afectos no meio urbano e escolar. In: Encontro da Associação de Pesquisadores em Artes Plásticas "Entre Territórios", 19o, 2010, Cachoeira/BA. Anais... Cachoeira: anpap, 2010. pp. 2556-2570. Disponível em:<http://www.anpap.org.br/anais/2010/pdf/ceav/valdemar_schultz.pdf>. Acesso em 06 de setembro de 2017.

LIMA, Mateus Vieira Villela de. Intervenção urbana: arte e resistência no espaço público. 2013. 45 f. Monografia (Especialização em Gestão de Projetos Culturais e Organização de Eventos). CELACC/ECA - Universidade de São Paulo (USP), São Paulo/SP, 2013.2 Disponivel em $<$ http://myrtus.uspnet.usp.br/celacc/sites/default/files/media/tcc/585-1621-1PB.pdf>. Acesso em 06 de Setembro de 2017.

CARDOSO, Arlindo da Silva. et al. Intervenções Urbanas. Disponível em $<w w w . k e n t r o n . i f a l . e d u . b r / i n d e x . p h p / e x t i f a l / a r t i c l e / d o w n l o a d / 161 / 114>$, acesso em 07 de setembro de 2017.

BARJA, Wagner. INTERVENÇÃO/TERIVENÇÃO: a arte de inventar e intervir diretamente sobre o urbano, suas categorias e o impacto no cotidiano. Disponível em 
< http://web.archive.org/web/20080425234854/http://www.polemica.uerj.br/pol15/ci magem/p15_barja.htm> Acesso em 08 de setembro de 2017.

FERREIRA, Núcia Sabóia. Intervenção Urbana no Ensino não Formal: Aproximando a Arte do Público em Sena Madureira. Disponível em <https://pt.slideshare.net/Vis-UAB/tcc-nucia-2011-final>. Acesso em 08 de setembro de 2017.

SILVA, Robson José Romano. Grafite em São Paulo: Entre a Comunicação a Céu aberto e a Comtemplarão nas Galerias de Arte. Disponível em <https://sapientia.pucsp.br/bitstream/handle/.../Robson\%20Jose\%20Romano\%20 Silva.pdf>. Acesso em 09 de Setembro de 2017.

NOBREGA, C. M. Interações(Não)Distantes: residências artísticas no Acre. 1. ed. Brasília: Programa de Pós-Graduação em Arte, 2013.

\section{Sites consultados}

https://www.intervencaourbana.org/

http://www.observatoriodasmetropoles.net/index.php?option=com_k2\&view=item\& id=1102\%3Achamada-livro-interven \%C3\%A7\%C3\%B5es-urbanas-naam\%C3\%A9rica-latina-napplac\%2Fusp\&Itemid=170\&lang=pt\#

https://www.historiadasartes.com/sala-dos-professores/intervencao-artisticaurbana/

http://enciclopedia.itaucultural.org.br/pessoa10593/cildo-meireles

http://www.inhotim.org.br/inhotim/arte-contemporanea/obras/desvio-para-overmelho-i-impregnacao-ii-entorno-iii-desvio-2/

http://www.mac.usp.br/mac/templates/projetos/seculoxx/modulo5/instalacao.html http://enciclopedia.itaucultural.org.br/termo3648/instalacao

http://www.eduardosrur.com.br/oartista/biografia 
http://enciclopedia.itaucultural.org.br/grupo434553/3nos3

http://enciclopedia.itaucultural.org.br/termo8882/intervencao

http://www.scielo.br/scielo.php?script=sci_arttext\&pid=S0102-

79721998000300014\&lng=en\&nrm=iso\&tIng=pt\#back 